

\section{Carbon Taxes: A Review of Experience and Policy Design Considerations}

\section{Technical Report}

NREL/TP-6A2-47312

December 2009

Jenny Sumner, Lori Bird, and Hillary Smith

Prepared under Task No. SAO9.2034

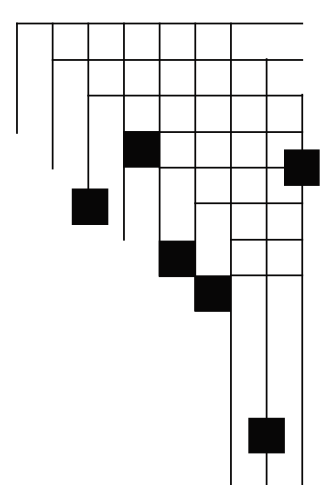

National Renewable Energy Laboratory

1617 Cole Boulevard, Golden, Colorado 80401-3393

303-275-3000 • www.nrel.gov

NREL is a national laboratory of the U.S. Department of Energy

Office of Energy Efficiency and Renewable Energy

Operated by the Alliance for Sustainable Energy, LLC

Contract No. DE-AC36-08-GO28308 


\section{NOTICE}

This report was prepared as an account of work sponsored by an agency of the United States government. Neither the United States government nor any agency thereof, nor any of their employees, makes any warranty, express or implied, or assumes any legal liability or responsibility for the accuracy, completeness, or usefulness of any information, apparatus, product, or process disclosed, or represents that its use would not infringe privately owned rights. Reference herein to any specific commercial product, process, or service by trade name, trademark, manufacturer, or otherwise does not necessarily constitute or imply its endorsement, recommendation, or favoring by the United States government or any agency thereof. The views and opinions of authors expressed herein do not necessarily state or reflect those of the United States government or any agency thereof.

Available electronically at http://www.osti.gov/bridge

Available for a processing fee to U.S. Department of Energy and its contractors, in paper, from:

U.S. Department of Energy

Office of Scientific and Technical Information

P.O. Box 62

Oak Ridge, TN 37831-0062

phone: 865.576 .8401

fax: 865.576 .5728

email: mailto:reports@adonis.osti.gov

Available for sale to the public, in paper, from:

U.S. Department of Commerce

National Technical Information Service

5285 Port Royal Road

Springfield, VA 22161

phone: 800.553.6847

fax: 703.605.6900

email: orders@ntis.fedworld.gov

online ordering: http://www.ntis.gov/ordering.htm 


\section{Acknowledgments}

This work was funded by the U.S. Department of Energy's (DOE's) Strategic Planning and Analysis Division of the Office of Energy Efficiency and Renewable Energy (EERE). The authors would like to thank David Rogers, Rebecca Garland, and Carla Frisch of DOE for their support of this work. In addition, the authors would like to thank the following reviewers for their thoughtful comments: Pelle Magdalinski, Swedish Environmental Protection Agency; Robert Noel de Tilly, Quebec Ministry of Sustainability, Environment, and Parks; Timo Parkkinen, Finnish Ministry of the Environment; Sarah Van Pelt, City of Boulder; and Jeffrey Logan, Robin Newmark, Daniel Steinberg, and Laura Vimmerstedt of NREL. In addition, we would like to thank the following individuals who provided helpful information and clarification of individual carbon tax policies: Brian Bateman, Bay Area Air Quality Management District; Anne Foy, Ministry of Finance in British Columbia; and Nick Hatherall, United Kingdom Climate Change and Energy Branch. Finally, the authors would also like to thank Mike Meshek of NREL for his editorial support. 


\section{Executive Summary}

State and local governments in the United States are evaluating a wide range of policies to reduce carbon emissions, including, in some instances, carbon taxes. Carbon taxes have existed internationally for nearly 20 years.

This report reviews existing carbon tax policies both internationally and in the United States. It also analyzes carbon policy design and effectiveness. Table ES-1 summarizes the carbon tax rates, annual revenue collected, and revenue distribution methods of existing and proposed carbon tax policies.

While each carbon tax is designed to meet the needs of the implementing jurisdiction, the implementation of all carbon taxes involves design considerations such as which sectors to tax, where to set the tax rate, how to use tax revenues, what the impact will be on consumers, and how to ensure emissions reduction goals are achieved.

Carbon taxes are most commonly placed on gasoline, coal, and natural gas. There are large differences among tax rates across various jurisdictions. The highest rates are paid in Sweden (\$105 per metric ton $\mathrm{CO}_{2}$ ), while the lowest rates are paid in the Bay Area Air Quality Management District (BAAQMD) in California ( $\$ 0.045$ per metric ton $\mathrm{CO}_{2}$ ). How jurisdictions set tax rates depends on what outcomes they are trying to achieve; higher rates can induce behavior change, while lower rates may be more appropriate to generate funds for carbon mitigation programs. Some jurisdictions, such as Sweden, allow industries to pay a reduced tax rate.

Revenue from carbon taxes can be distributed in several ways. Some jurisdictions (e.g., Boulder, Quebec, BAAQMD) use the revenue for carbon mitigation programs. Other jurisdictions (e.g., United Kingdom, British Columbia, France's proposed policy) return carbon tax revenue to customers. Sweden and Norway use carbon tax revenues to fund general government budgets. Finland's carbon tax also is directed to the general government budget, but it is accompanied by a cut in income tax. In some cases, carbon tax revenues have been redirected to low-income consumers to minimize impacts.

While carbon taxes are often touted as the more economically efficient means of addressing carbon emissions, they may not ensure a set level of emissions reductions. Carbon taxes can be designed so that tax rates increase automatically if emission reductions are not met, though this practice has not been fully implemented to date.

Emission reductions that are due to carbon taxes can be difficult to measure. Some jurisdictions have quantified reductions in overall emissions, while other jurisdictions have examined impacts that are due to programs funded by carbon tax revenues.

Carbon tax policies can also be integrated with other carbon policies to maximize greenhouse gas (GHG) reductions. In Europe, countries implementing a carbon tax also operate within the European Union's Emissions Trading Scheme. Other complementary policies such as Norway's tax on hydrofluorocarbons (HFCs) and perfluorocompounds (PFCs) can address different GHGs. 
Table ES-1. Overview of Carbon Tax Policies

\begin{tabular}{|c|c|c|c|c|}
\hline $\begin{array}{l}\text { Countryl } \\
\text { Jurisdiction }\end{array}$ & $\begin{array}{l}\text { Start } \\
\text { Date }\end{array}$ & $\begin{array}{c}\text { Tax Rate } \\
\text { (\$USD unless noted otherwise) }\end{array}$ & $\begin{array}{l}\text { Annual } \\
\text { Revenue }\end{array}$ & $\begin{array}{l}\text { Revenue } \\
\text { Distribution }\end{array}$ \\
\hline Finland & 1990 & $\$ 30 /$ metric ton $\mathrm{CO}_{2}(€ 20)$ & $\begin{array}{l}\$ 750 \text { million } \\
(€ 500 \text { million })\end{array}$ & $\begin{array}{l}\text { Government budget; } \\
\text { accompanied by independent } \\
\text { cuts in income taxes }\end{array}$ \\
\hline Netherlands & 1990 & $\sim \$ 20 /$ metric ton $\mathrm{CO}_{2}$ in 1996 & $\begin{array}{l}\$ 4.819 \text { billion }^{\mathrm{a}} \\
(€ 3.213 \text { billion })\end{array}$ & $\begin{array}{l}\text { Reductions in other taxes; } \\
\text { Climate mitigation programs }\end{array}$ \\
\hline Norway & 1991 & $\begin{array}{l}\$ 15.93 \text { to } \$ 61.76 / \text { metric ton } \mathrm{CO}_{2} \\
\text { (NOK } 89 \text { to NOK } 345 \text { ) }\end{array}$ & $\begin{array}{l}\$ 900 \text { million } \\
\text { (1994 estimate) }\end{array}$ & Government budget \\
\hline Sweden & 1991 & $\begin{array}{l}\text { Standard rate: } \$ 104.83 / \text { metric ton } \mathrm{CO}_{2} \\
(910 \text { SEK) } \\
\text { Industry rate: } \sim \$ 23.04 / \text { metric ton } \mathrm{CO}_{2} \\
(\sim 200 \text { SEK) }\end{array}$ & $\begin{array}{l}\text { \$3.665 billion } \\
\text { ( } 25 \text { billion SEK) }\end{array}$ & Government budget \\
\hline Denmark & 1992 & $\$ 16.41 /$ metric ton $\mathrm{CO}_{2}(90 \mathrm{DKK})$ & $\$ 905$ million & $\begin{array}{l}\text { Environmental subsidies and } \\
\text { returned to industry }\end{array}$ \\
\hline $\begin{array}{l}\text { United } \\
\text { Kingdom }\end{array}$ & 2001 & $\begin{array}{l}\$ 0.0078 / \mathrm{kWh} \text { for electricity; } \$ 0.0027 / \mathrm{kWh} \\
\text { for natural gas provided by gas utility; } \\
\$ 0.0175 / \mathrm{kg} \text { for liquefied petroleum gas or } \\
\text { other gaseous hydrocarbons supplied in a } \\
\text { liquid state; and } \$ 0.0213 / \mathrm{kg} \text { for solid fuel }\end{array}$ & $\begin{array}{l}\$ 1.191 \text { billion } \\
(£ 714 \text { million })\end{array}$ & Reductions in other taxes \\
\hline Boulder, CO & 2007 & $\$ 12-13$ per metric ton $\mathrm{CO}_{2}$ & $\$ 846,885$ & Climate mitigation programs \\
\hline Quebec & 2007 & $\$ 3.20$ per metric ton of $\mathrm{CO}_{2}(\mathrm{C} \$ 3.50)$ & $\begin{array}{l}\text { \$191 million } \\
\text { (C } \$ 200 \text { million) }\end{array}$ & Climate mitigation programs \\
\hline $\begin{array}{l}\text { British } \\
\text { Columbia }\end{array}$ & 2008 & $\begin{array}{l}\$ 9.55 \text { per metric ton of } \mathrm{CO}_{2} \text { in } 2008(\mathrm{C} \$ 10) \text {, } \\
\text { increasing } \$ 4.77(\mathrm{C} \$ 5) \text { annually to } \$ 28.64 \\
(\mathrm{C} \$ 30) \text { in } 2012\end{array}$ & $\begin{array}{l}\text { \$292 million } \\
\text { (C\$306 million) }\end{array}$ & Reductions in other taxes \\
\hline $\begin{array}{l}\text { BAAQMD, } \\
\text { California }\end{array}$ & 2008 & $\$ 0.045$ per metric ton of $\mathrm{CO}_{2} \mathrm{e}^{\mathrm{b}}$ & $\begin{array}{l}\$ 1.1 \text { million } \\
\text { (expected) }\end{array}$ & Climate mitigation programs \\
\hline France & proposed & $\$ 24.74$ per metric ton of $\mathrm{CO}_{2}(€ 17)$ & $\begin{array}{l}\$ 4.499 \text { billion } \\
\text { (€3 billion) } \\
\text { expected }\end{array}$ & Reductions in other taxes \\
\hline $\begin{array}{l}\text { CARB, } \\
\text { California }\end{array}$ & proposed & $\begin{array}{l}\$ 0.155 \text { per metric ton } \mathrm{CO}_{2} \mathrm{e} \text { in } \mathrm{FY} 2010-11 \text {, } \\
\text { dropping to } \$ 0.09 \text { per metric ton } \mathrm{CO}_{2} \mathrm{e} \text { in } \\
2014\end{array}$ & $\begin{array}{l}\$ 63.1 \text { million } 2010- \\
2013 ; \$ 36.2 \text { million } \\
\text { starting in } 2014 \text {, } \\
\text { expected }\end{array}$ & Climate mitigation programs \\
\hline
\end{tabular}




\section{Table of Contents}

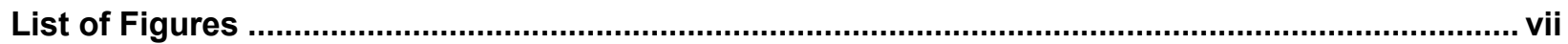

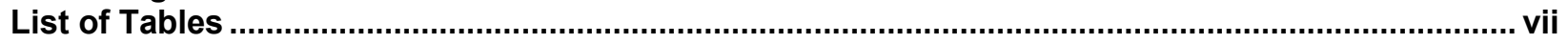

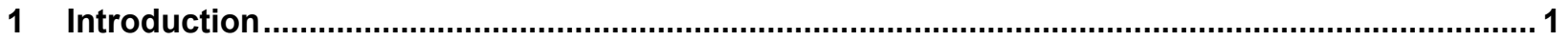

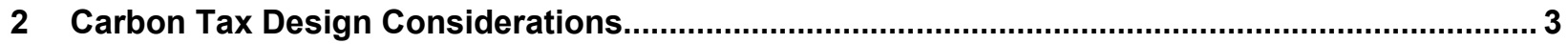

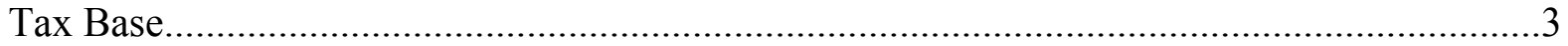

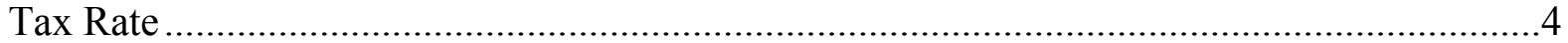

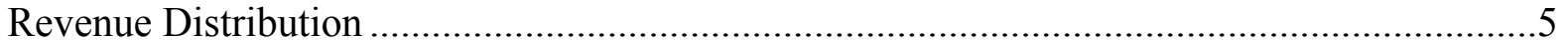

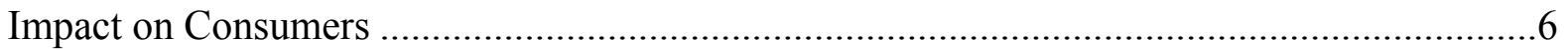

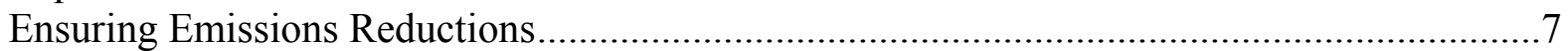

3 Carbon Taxes Implemented Since 1990

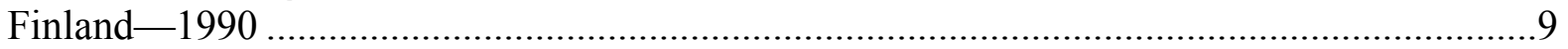

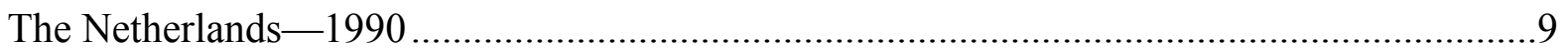

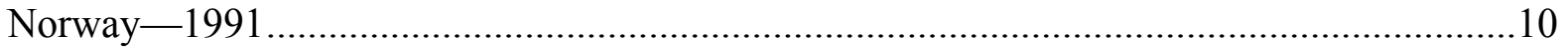

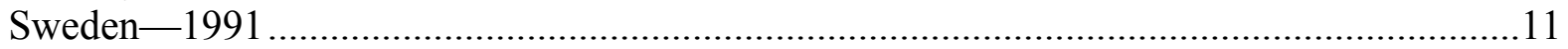

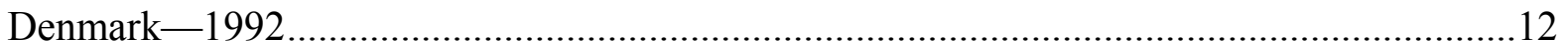

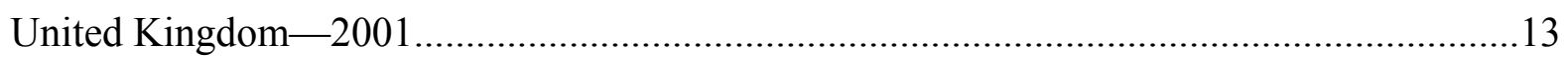

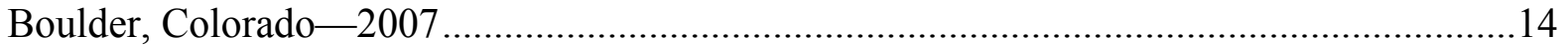

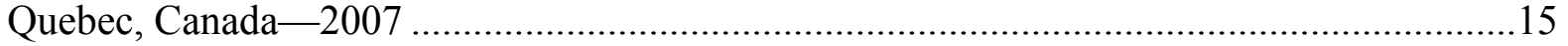

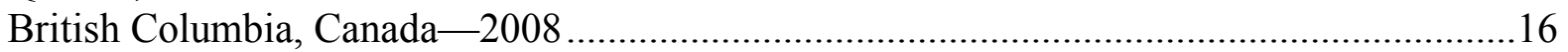

Bay Area Air Quality Management District, California — 2008 .......................................... 17

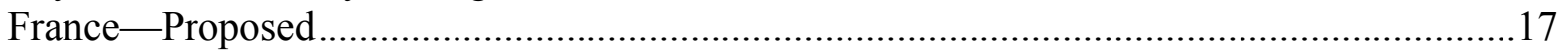

California Air Resource Board_Proposed .................................................................... 18

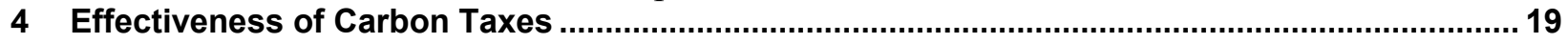

Evaluation of Emissions Benefits of Carbon Taxes ..............................................................19

Benefits of Programs Funded by Carbon Tax Revenues ...................................................21

Program Evaluation and Adjustments to Carbon Tax Levels...............................................21

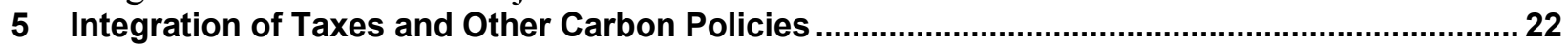

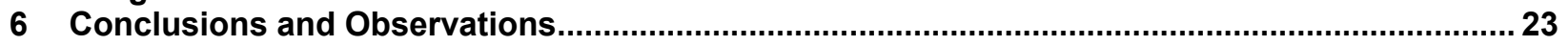

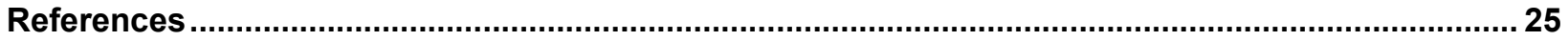

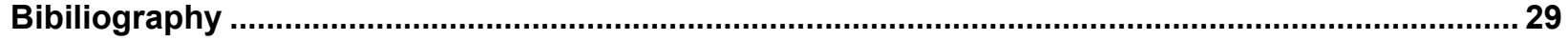




\section{List of Figures}

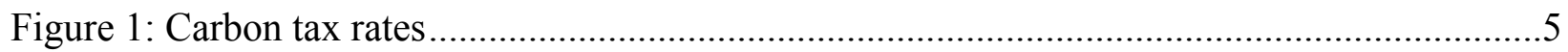

Figure 2. Swedish $\mathrm{CO}_{2}$ tax rate, SEK per kilogram $\mathrm{CO}_{2}$, nominal figures...................................11

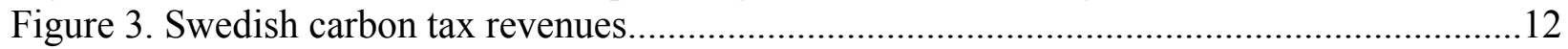

\section{List of Tables}

Table ES-1. Overview of Carbon Tax Policies .. $\mathrm{V}$

Table 1. Major Taxed Sectors in Existing and Proposed Carbon Tax Systems ...............................

Table 2. Overview of Carbon Tax Policies..............................................................................

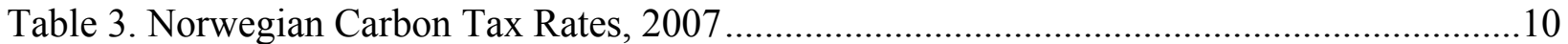

Table 4. Danish Energy and $\mathrm{CO}_{2}$ Tax on Various Fuel Types ...................................................13

Table 5. United Kingdom Climate Change Levy Rates as of April 1, 2009 .................................14

Table 6. Estimated Emissions Reductions in Jurisdictions with Carbon Taxes .............................20 


\section{Introduction}

Carbon taxes have existed internationally for nearly 20 years. In the early 1990 s, carbon taxes emerged in northern European countries, with Finland being the first nation to adopt a carbon tax in 1990. Subsequently, the Netherlands (1990), Norway (1991), Sweden (1991), and Denmark (1992) implemented carbon taxes. More than a decade after the first carbon tax, in 2001, the United Kingdom began its Climate Change Levy.

Interest in federal carbon policy has recently increased in the United States. The U.S. House of Representatives passed H.R.2454 "The American Clean Energy and Security Act of 2009" ("Waxman-Markey bill") in June 2009, and the U.S. Senate introduced S.1733 "Clean Energy Jobs and American Power Act" ("Kerry-Boxer bill") in September 2009. While recent federal policy has focused on carbon cap and trade policies, Congress introduced three carbon tax bills in 2009. ${ }^{1}$ Proposals vary, but each taxes fossil fuel production and imports between $\$ 10$ and $\$ 15$ per short ton of carbon dioxide $\left(\mathrm{CO}_{2}\right)$ in the first year and creates plans to increase the tax over time.

As a policy mechanism, carbon taxes have been extensively compared to carbon cap and trade systems. In terms of economic efficiency, carbon taxes are expected to generate more net benefits than a cap and trade system, which is inherently inflexible. The Congressional Budget Office (CBO) surveyed current literature and estimated that the net benefits of a tax could be roughly five times those of an inflexible cap with no banking, borrowing, or other cost containment mechanisms (CBO 2008). One benefit of a carbon tax is that it continuously encourages emissions reductions, whereas a cap and trade system only encourages reductions to the point of the cap. Further, taxes are straightforward to administer and less subject to gaming. Taxes are also viewed as beneficial because the price is known, in contrast with a cap and trade system, which can create volatile prices, because of the unpredictable nature of supply, demand, and regulatory conditions (Nordhaus 2008). Also, taxes create revenue, which can be used to address distributional inequities by returning it to low-income consumers.

However, the primary criticism of taxes is that they do not necessarily ensure a certain level of emissions reductions as emissions caps do. Carbon taxes are often viewed as less politically acceptable than cap and trade systems. Despite the distinctions often made between the two policies, a pure carbon cap and trade system could be modified to address benefits that carbon taxes provide. A carbon cap and trade system could allow banking and borrowing of allowances or other cost containment mechanisms, thus decreasing price volatility. It could also raise revenue - by auctioning allowances - and distribute the revenue to low-income consumers. A review of the first compliance period of the European Union's Emission Trading Scheme (ETS) found that the program evolved "surprisingly well" and was able to establish a transparent price on tradable $\mathrm{CO}_{2}$ emission allowances (Ellerman and Joskow 2008).

In the most recent wave of carbon taxes, state and local governments have become more active in adopting taxes as either a complement to federal policies or a reaction to lack of federal

\footnotetext{
${ }^{1}$ Representative Stark (D-CA) introduced H.R.594 "Save Our Climate Act of 2009" in January 2009, Representative Larson introduced H.R.1337 “America's Energy Security Trust Fund Act of 2009” in March 2009, and Representative Inglis (R-SC) introduced H.R.2380 "Raise Wages, Cut Carbon Act of 2009" in May 2009.
} 
leadership. In 2007, Boulder, Colorado and Quebec, Canada introduced carbon taxes, and in 2008, British Columbia, Canada, and the Bay Area Air Quality Management District (BAAQMD) in California began implementing carbon taxes. France and the California Air Resources Board (CARB) proposed carbon taxes in 2009.

There is also increasing interest in combining carbon taxes with other carbon mitigation policies. Carbon cap and trade systems may not cover all sectors or may be more difficult to implement in sectors without point sources (e.g., transportation); therefore, carbon taxes may be designed to work in conjunction with other carbon policies. For example, the recently proposed French carbon tax is designed to cover sectors not addressed by the European Union's ETS.

This paper discusses considerations in the design of carbon taxes and reviews experience implementing carbon taxes domestically and internationally. It also discusses the effectiveness of these policies and difficulties measuring impacts. Measures of effectiveness can vary by jurisdiction and specific policy goals. While all carbon taxes at their core are designed to reduce $\mathrm{CO}_{2}$ or GHG emissions, some taxes may be aggressive in their efforts to encourage changes in behavior and consumption patterns, while others may be implemented at more modest levels to generate revenues to support the expansion or cost effectiveness of low-carbon technologies. Effectiveness has been evaluated based on (1) aggregate carbon emissions reductions in the jurisdiction, (2) emissions reductions that are due to the tax, and (3) emissions reductions from programs implemented with tax revenue. 


\section{Carbon Tax Design Considerations}

Carbon taxes place a value on $\mathrm{CO}_{2}$ and other $\mathrm{GHG}$ emissions, thus internalizing some portion of the costs associated with their environmental impact. While all carbon taxes inherently provide this function, policy goals may vary. Carbon taxes serve primarily to reduce GHG emissions by placing a cost on emissions, but can also raise revenues to provide funding for carbon mitigation programs or create market signals for consumers. Policy design considerations associated with implementing carbon taxes include determining the tax base, which sectors to tax, where to set the tax rate, how to use tax revenues, how to assess the impact on consumers, and how to ensure the tax achieves emissions reduction goals.

\section{Tax Base}

To implement carbon taxes, governments must decide which fuels or sources to place the tax. Most commonly, carbon taxes are placed on gasoline, coal, and natural gas. Some governments, however, exempt certain industries from carbon taxes or allow those industries to pay lower tax rates.

Governments must also decide whether to place the tax on upstream or downstream sources of emissions. Taxing upstream sources may provide an administratively efficient method of tax collection, while taxing downstream sources such as electricity consumption may provide a more direct signal to consumers. Although this debate is not the focus of this paper, it is important to recognize the potential effects of taxing upstream versus downstream sources when designing a carbon tax.

When considering which sectors to tax, some governments may also be limited by their jurisdictions. For example, the BAAQMD has authority to control air pollution for non-vehicular stationary sources, thus the primary sectors taxed include petroleum refineries, power plants, cement plants, and landfills. Table 1 summarizes the major fuels or sources on which current carbon taxes are applied in the 12 jurisdictions described in Section 3. 
Natural gas

Gasoline

Coal

Electricity

Diesel

Light and heavy fuel oil

Liquified petroleum gas

(LPG)

Home heating oil

Permitted facilities

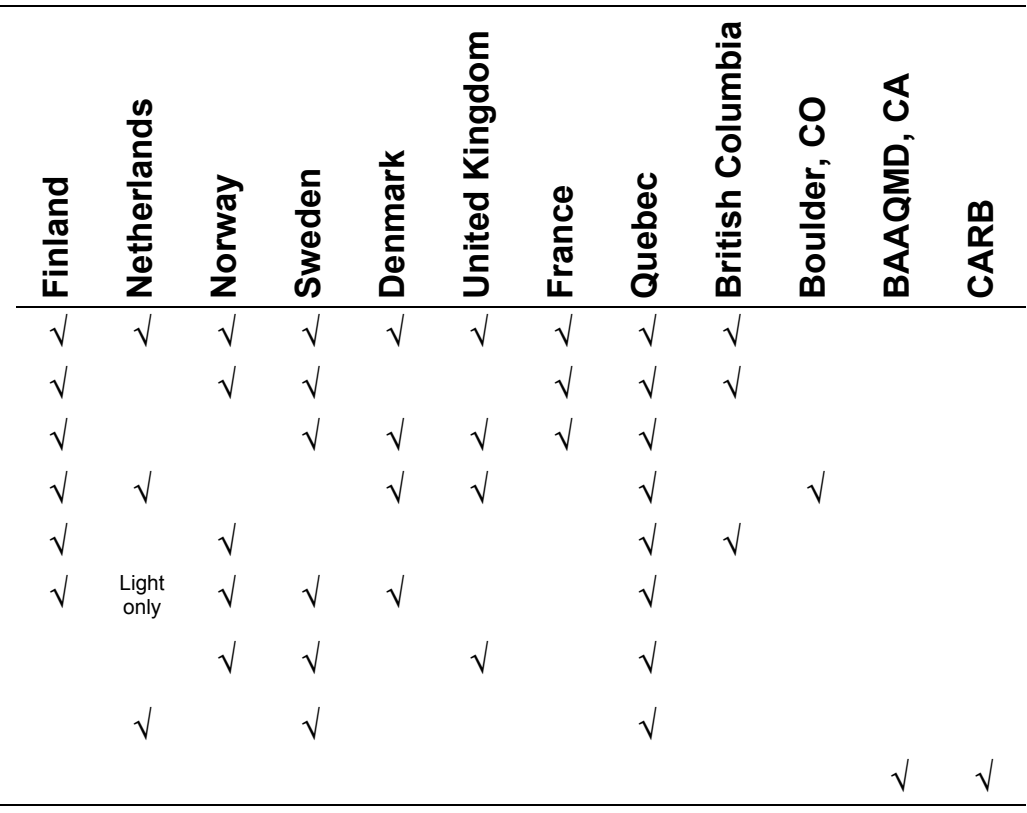

\section{Tax Rate}

As shown in Figure 1, carbon tax rates vary across jurisdictions, in part due to their function. Higher carbon tax rates provide stronger signals to consumers to change behavior, while lower rates may not do much to change behavior but can provide funds for carbon mitigation programs.

Some of the highest rates are seen in Europe ${ }^{2}$ : Sweden's standard tax rate is the equivalent of $\$ 105$ per metric ton $\mathrm{CO}_{2}$; however, the rate for industry is substantially less at $\$ 23$ per metric ton $\mathrm{CO}_{2}$. Norway's tax on gasoline equates to $\$ 62$ per metric ton $\mathrm{CO}_{2}$ and Finland's tax is $\$ 30$ per metric ton $\mathrm{CO}_{2}$. France's proposed tax rate is modeled after the current price for $\mathrm{CO}_{2}$ allowances in the European Union's ETS and is set at the equivalent of about $\$ 25$ per metric ton $\mathrm{CO}_{2}$.

Some of the lowest rates occur in California. The BAAQMD rate is $\$ 0.045$ per metric ton $\mathrm{CO}_{2}$, and the BAAQMD explicitly designed the tax to raise revenue to support local GHG mitigation programs rather than to encourage behavior change. The proposed CARB tax rate is also set comparatively low, at $\$ 0.155$ per metric ton $\mathrm{CO}_{2}$, and is designed to generate funds for GHG mitigation programs.

\footnotetext{
${ }^{2}$ In this paper, unless otherwise noted, foreign currencies have been converted to U.S. dollars using contemporary exchange rates for the given year of revenue or expenditure. If no year of the tax or expenditure is stated, a current exchange rate is used.
} 


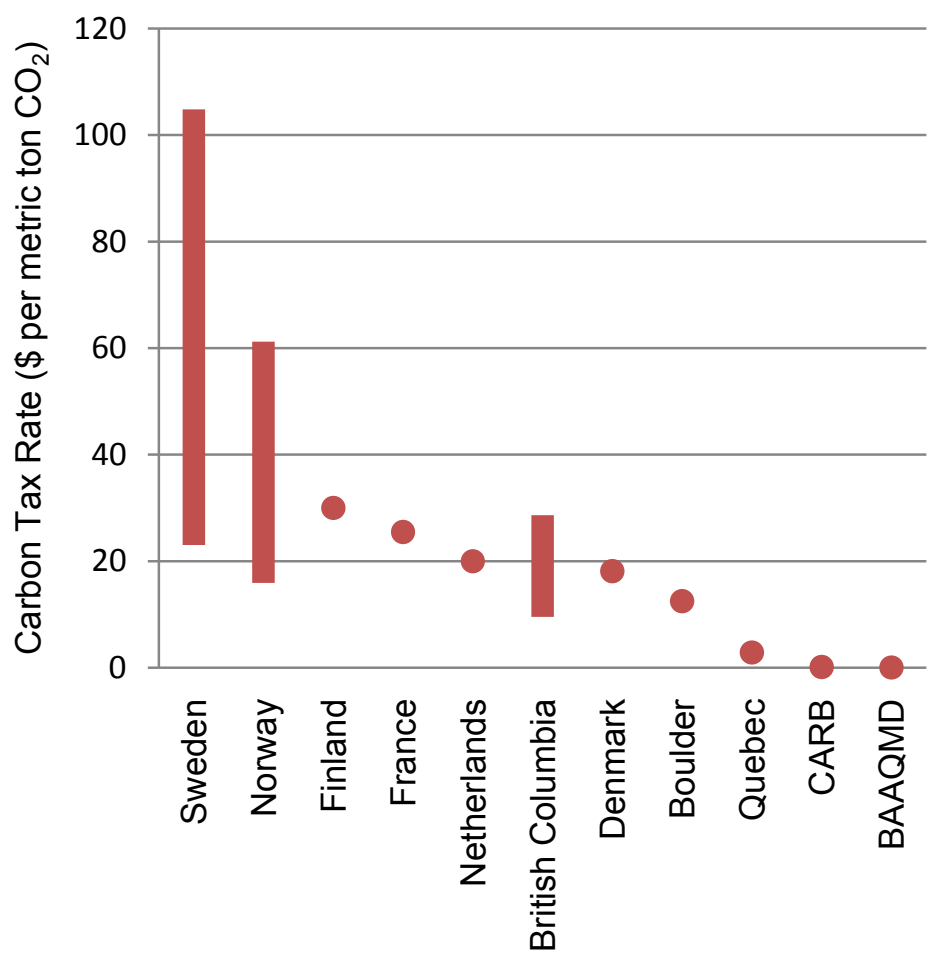

Notes: Sweden and Norway's carbon tax rates vary depending on the taxed sector. British Columbia's carbon tax was $\mathrm{C} \$ 10(\$ 9.55)$ per metric ton $\mathrm{CO}_{2}$ in 2008 but is scheduled to increase by $\mathrm{C} \$ 5$ per year to $\mathrm{C} \$ 30(\$ 28.64)$ in 2012.

Figure 1: Carbon tax rates

\section{Revenue Distribution}

Revenues from carbon taxes are directed in different ways. Revenues can be (1) directed specifically to carbon mitigation programs, (2) directed to individuals through measures, such as reductions in income taxes, or (3) used to supplement government budgets. The choice of revenue distribution could impact the political sustainability of the tax.

State and local governments frequently direct carbon tax revenues to carbon reduction programs that they implement. Boulder, Quebec, and the BAAQMD all use revenues for carbon mitigation programs, and CARB has proposed to do so as well.

Some carbon tax programs return tax revenue to customers through other means such as income tax reductions. The United Kingdom and British Columbia use this method, and France has proposed refunding revenue as well. Finland's approach does not earmark the carbon tax revenue, but the tax is accompanied by independent cuts in income taxes (Parkkinen 2009). These "revenue-neutral" mechanisms, which are designed to change customer behavior while reducing other taxes, do not raise money for government general funds or emission reduction programs. The "double dividend" theory suggests that revenue-neutral policies create two benefits: a price is placed on goods that harm the environment and lowered income taxes will spur new employment opportunities (OECD 2001). A revenue-neutral approach can also lower the overall economic impacts of implementing a carbon tax (Repetto 2001). Cost savings are also greater when tax revenues are returned through cuts in distorting taxes (such as income taxes) 
than when they are returned in lump sums. These results have been both demonstrated by economic theory and supported by numerical simulations. (Goulder 1995)

On the other hand, some carbon taxes, like those in Sweden and Norway, are used specifically to raise revenue for governments. Directing revenues to general government budgets can be easier to administer than funding carbon mitigation programs. However, critics say that carbon taxes simply are a way to raise government revenue rather than provide environmental benefits. If governments were to raise tax rates purely to increase revenue, the resulting tax would not be economically efficient - for an efficient tax, the rate should be set equal to the marginal damage caused by carbon emissions. An alternative approach would direct revenue to programs that address environmental impact through earmarking, thus limiting the incentive to raise taxes purely to generate more revenue. (Prasad 2008)

\section{Impact on Consumers}

When designing a carbon tax, the impact on low-income households is also a consideration; a common criticism of carbon taxes is that they disproportionately burden low-income households. Several policies, including income tax reductions and credits to low-income households, can be used to mitigate this concern. For example, British Columbia provides a low-income "climate action tax credit," a reduction of 5\% in the first two personal income tax rates, and has proposed providing a Northern and Rural Homeowner benefit of up to \$200 in 2011 (Ministry of Finance, British Columbia 2008). British Columbia estimated the net impact of the carbon tax and other associated tax cuts for two respective family types (seniors and a two-earner family of four), finding that the tax cuts exceed the cost of the carbon tax in both cases. ${ }^{3}$ (Ministry of Finance, British Columbia 2008)

In France, President Nicolas Sarkozy proposed plans to return all revenues to households and businesses through reductions in income taxes or through issuing a "green check" (Keller 2009). While not explicitly addressing low-income consumers, France's proposal would help lowincome households adapt to the carbon tax.

Carbon taxes impact businesses. Businesses may prefer carbon taxes to other carbon mitigation policies, because taxes provide a certain, long-term price signal that can be incorporated into projections of operating expenses, whereas prices may not be as well known with emissions caps. Energy-intensive industries or highly competitive industries that compete with companies in jurisdictions without taxes have expressed concerns about carbon taxes. To address concerns about the impact of carbon taxes on businesses, some jurisdictions allow certain industries to pay reduced rates. Sweden's reduced rate for industry is approximately $\$ 23$ per metric ton $\mathrm{CO}_{2}$, while the standard rate is $\$ 105$ per metric ton $\mathrm{CO}_{2}$. In Denmark, businesses that sign an energy

\footnotetext{
${ }^{3}$ In 2009 , a two-earner family of four earning $\mathrm{C} \$ 60,000$ per year would pay carbon taxes of $\mathrm{C} \$ 60$ for gasoline and $\mathrm{C} \$ 53$ for natural gas heat and hot water, but it would receive a personal income tax reduction of $\mathrm{C} \$ 118$, thus receiving a net gain of $\mathrm{C} \$ 5$. These figures assume 23 miles per gallon fuel efficiency and approximately 12,400 miles of driving per year. A senior couple earning $C \$ 30,000$ per year would pay carbon taxes of $C \$ 25$ for gasoline and C\$70 for an oil furnace using 2,000 liters of heating oil per year. The senior couple would receive C\$205 in personal income tax reduction, thus making the net gain for the couple $\mathrm{C} \$ 110$. These figures assume 19.6 miles per gallon fuel efficiency and approximately 4,300 miles of driving per year. (Ministry of Finance, British Columbia 2008)
} 
savings agreement with the Ministry of Transportation and Energy can pay reduced rates. Denmark also reduced existing taxes on energy when it established a carbon tax, so that the effective tax rate was the same.

\section{Ensuring Emissions Reductions}

One of the key arguments against carbon taxes and in favor of emissions limits is that taxes do not necessarily guarantee emissions reductions. While a tax policy could be structured so that rates automatically increase if emissions reduction goals are not met, this approach has not been implemented. This may reflect the political challenges of passing a tax in the first place. In fact, many taxes are structured in ways to make them more politically feasible. Revenue-neutral policies and refunds to low-income consumers are designed to make policies more politically appealing.

Some governments have increased their tax rates over time, but none has implemented a policy to increase automatically if emissions reduction targets are not met. British Columbia's carbon tax is set to phase in over a four-year period and the government has indicated it will modify the tax if necessary to achieve carbon emissions goals over time; however, because the tax was only recently implemented, there have not been any attempts to modify the tax rate yet. Governments operating GHG-reduction programs may find it easier to modify programs than to raise taxes. Quebec publishes an annual progress report on its GHG-reduction programs. The City of Boulder increased rates to the maximum allowed by their ordinance and directed the additional revenues to implement more GHG-reduction programs. The BAAQMD has indicated that it may raise fees in the future, depending on the need of its Carbon Protection Program. 


\section{Carbon Taxes Implemented Since 1990}

While the first implemented carbon tax is approaching its twentieth year of implementation, there have been few reviews of carbon tax policies. Current literature focuses on the economic efficiency of carbon taxes compared to carbon cap and trade systems. This section examines existing carbon taxes, specifically looking at the sectors taxed, the tax rate, and annual revenue generated.

Table 2. Overview of Carbon Tax Policies

\begin{tabular}{|c|c|c|c|c|}
\hline $\begin{array}{l}\text { Countryl } \\
\text { Jurisdiction }\end{array}$ & $\begin{array}{l}\text { Start } \\
\text { Date }\end{array}$ & $\begin{array}{c}\text { Tax Rate } \\
\text { (\$USD unless noted otherwise) }\end{array}$ & $\begin{array}{l}\text { Annual } \\
\text { Revenue }\end{array}$ & $\begin{array}{c}\text { Revenue } \\
\text { Distribution }\end{array}$ \\
\hline Finland & 1990 & $\$ 30 /$ metric ton $\mathrm{CO}_{2}(€ 20)$ & $\begin{array}{l}\$ 750 \text { million } \\
(€ 500 \text { million })\end{array}$ & $\begin{array}{l}\text { Government budget; } \\
\text { accompanied by independent } \\
\text { cuts in income taxes }\end{array}$ \\
\hline Netherlands & 1990 & $\sim$ \$20/metric ton $\mathrm{CO}_{2}$ in 1996 & $\begin{array}{l}\$ 4.819 \text { billion }^{\mathrm{a}} \\
\text { (€3.213 billion) }\end{array}$ & $\begin{array}{l}\text { Reductions in other taxes; } \\
\text { Climate mitigation programs }\end{array}$ \\
\hline Norway & 1991 & $\begin{array}{l}\$ 15.93 \text { to } \$ 61.76 / \text { metric ton } \mathrm{CO}_{2} \\
\text { (NOK } 89 \text { to NOK } 345 \text { ) }\end{array}$ & $\begin{array}{l}\$ 900 \text { million } \\
\text { (1994 estimate) }\end{array}$ & Government budget \\
\hline Sweden & 1991 & $\begin{array}{l}\text { Standard rate: } \$ 104.83 / \text { metric ton } \mathrm{CO}_{2} \\
\text { (910 SEK) } \\
\text { Industry rate: } \sim \$ 23.04 / \text { metric ton } \mathrm{CO}_{2} \\
(\sim 200 \text { SEK) }\end{array}$ & $\begin{array}{l}\text { \$3.665 billion } \\
\text { ( } 25 \text { billion SEK) }\end{array}$ & Government budget \\
\hline Denmark & 1992 & $\$ 16.41 /$ metric ton $\mathrm{CO}_{2}(90 \mathrm{DKK})$ & $\$ 905$ million & $\begin{array}{l}\text { Environmental subsidies and } \\
\text { returned to industry }\end{array}$ \\
\hline $\begin{array}{l}\text { United } \\
\text { Kingdom }\end{array}$ & 2001 & $\begin{array}{l}\$ 0.0078 / \mathrm{kWh} \text { for electricity; } \$ 0.0027 / \mathrm{kWh} \\
\text { for natural gas provided by gas utility; } \\
\$ 0.0175 / \mathrm{kg} \text { for liquefied petroleum gas or } \\
\text { other gaseous hydrocarbons supplied in a } \\
\text { liquid state; and } \$ 0.0213 / \mathrm{kg} \text { for solid fuel }\end{array}$ & $\begin{array}{l}\$ 1.191 \text { billion } \\
\text { (£714 million) }\end{array}$ & Reductions in other taxes \\
\hline Boulder, CO & 2007 & $\$ 12-13$ per metric ton $\mathrm{CO}_{2}$ & $\$ 846,885$ & Climate mitigation programs \\
\hline Quebec & 2007 & $\$ 3.20$ per metric ton of $\mathrm{CO}_{2}(\mathrm{C} \$ 3.50)$ & $\begin{array}{l}\text { \$191 million } \\
\text { (C } \$ 200 \text { million) }\end{array}$ & Climate mitigation programs \\
\hline $\begin{array}{l}\text { British } \\
\text { Columbia }\end{array}$ & 2008 & $\begin{array}{l}\$ 9.55 \text { per metric ton of } \mathrm{CO}_{2} \text { in } 2008(\mathrm{C} \$ 10) \text {, } \\
\text { increasing } \$ 4.77(\mathrm{C} \$ 5) \text { annually to } \$ 28.64 \\
(\mathrm{C} \$ 30) \text { in } 2012\end{array}$ & $\begin{array}{l}\$ 292 \text { million } \\
\text { (C\$306 million) }\end{array}$ & Reductions in other taxes \\
\hline $\begin{array}{l}\text { BAAQMD, } \\
\text { California }\end{array}$ & 2008 & $\$ 0.045$ per metric ton of $\mathrm{CO}_{2} \mathrm{e}^{\mathrm{b}}$ & $\begin{array}{l}\$ 1.1 \text { million } \\
\text { (expected) }\end{array}$ & Climate mitigation programs \\
\hline France & proposed & $\$ 24.74$ per metric ton of $\mathrm{CO}_{2}(€ 17)$ & $\begin{array}{l}\$ 4.499 \text { billion } \\
\text { (€3 billion) } \\
\text { expected }\end{array}$ & Reductions in other taxes \\
\hline $\begin{array}{l}\text { CARB, } \\
\text { California }\end{array}$ & proposed & $\begin{array}{l}\$ 0.155 \text { per metric ton } \mathrm{CO}_{2} \mathrm{e} \text { in } \mathrm{FY} 2010-11 \text {, } \\
\text { dropping to } \$ 0.09 \text { per metric ton } \mathrm{CO}_{2} \mathrm{e} \text { in } \\
2014\end{array}$ & $\begin{array}{l}\$ 63.1 \text { million } 2010- \\
2013 ; \$ 36.2 \text { million } \\
\text { starting in } 2014, \\
\text { expected }\end{array}$ & Climate mitigation programs \\
\hline
\end{tabular}

\footnotetext{
${ }^{a}$ Revenue in the Netherlands is from all environmentally related taxes, of which carbon taxes are the clear majority.

${ }^{\mathrm{b}} \mathrm{CO}_{2} \mathrm{e}$ is carbon dioxide equivalent.
} 


\section{Finland-1990}

Finland was the first country to adopt a carbon tax. Launched in 1990, Finland's carbon tax is a separate component of Finland's excise tax on fossil fuels used for transportation or heating. The carbon tax applies to gasoline, diesel, light fuel and heavy fuel oil, jet fuel, aviation gasoline, coal, and natural gas (Ministry of the Environment, Finland 2008a). Coal is subject to a tax of $\$ 73.97$ (€49.32) per metric ton, natural gas is subject to a reduced tax rate of $\$ 3.02(€ 2.016)$ per MWh, and liquid fuels are taxed between \$0.07 (€0.05) and \$0.09 (€0.06) per liter (European Environment Agency 2009). Commercial vessels and commercial air traffic as well as fuels used for electricity are exempt. Electricity is taxed, but the rate per kWh does not vary according to carbon content; however, a refund is available for renewable electricity. (Parkkinen 2009)

Initially, Finland based its carbon tax purely on carbon content but modified it to include a $60 \%$ carbon component and a 40\% energy component. The energy component was a tax based on energy use in MWh rather than on carbon content of the fuel. In January 1997, however, Finland returned to a pure carbon tax (Parkkinen 2009). The carbon tax was most recently increased by $13 \%$ to $\$ 30(€ 20)$ per metric ton $\mathrm{CO}_{2}$ on January 1, 2008 (Ministry of Environment Finland $2008 b)$. Carbon tax revenues have been approximately $\$ 750$ million ( $€ 500$ million) annually (Ministry of Environment Finland 2008b). All revenue from the carbon tax in Finland goes directly into the general central government budget without any earmarking (Parkkinen 2009).

In 2000, the Finnish government determined that because of the carbon tax, $\mathrm{CO}_{2}$ emissions were reduced by roughly 4 million metric tons of $\mathrm{CO}_{2}$ between 1990 and 1998. Four million metric tons of $\mathrm{CO}_{2}$ represented approximately $7 \%$ of the 57 million metric tons of emissions recorded in 1998 (Prime Minister's Office, Finland 2000).

\section{The Netherlands-1990}

The Netherlands' carbon tax began in 1990. It applies to natural gas, electricity, blast furnaces, coke ovens, refinery and coal gas, coal gasification gas, gasoline, diesel, and light fuel. In 1996, the tax rate was equivalent to $\$ 20$ per metric ton $\mathrm{CO}_{2}$.

Environmentally related taxes generate total revenue of $\$ 4.819$ billion ( $€ 3.213$ billion), of which the carbon tax is the majority (Netherlands Ministry of Housing, Spatial Planning and the Environment n.d.).

The Netherlands uses carbon tax revenues to reduce the general tax burden for individuals and businesses as well as to provide programs to reduce greenhouse gases. Part of the revenue is "recycled" to businesses in the form of accelerated depreciation for environmental equipment and tax-deductibility of energy investments (Netherlands Ministry of Housing, Spatial Planning and the Environment, Directorate-General for Environmental Protection, n.d.).

The Netherlands Ministry of Housing, Spatial Planning and the Environment (n.d.) estimated the carbon tax would reduce annual $\mathrm{CO}_{2}$ emissions 1.7 to 2.7 million metric tons annually in 2000, with covered sectors reducing $\mathrm{CO}_{2}$ emissions by approximately $5 \%$. Due to an increase in the tax in 1999, annual $\mathrm{CO}_{2}$ emissions are projected to be reduced 3.6 to 3.8 million tons by 2010 and 4.6 to 5.1 million tons in 2020 . 


\section{Norway-1991}

Norway's carbon tax began in 1991. The current tax rates vary from $\$ 15.93$ (NOK 89) per metric ton $\mathrm{CO}_{2}$ to $\$ 61.76$ (NOK 345) per metric ton $\mathrm{CO}_{2}$ (Ministry of the Environment, Norway 2007). Taxed sectors include gasoline, light and heavy fuel oil, and oil and gas in the North Sea. The pulp and paper industry, fishmeal industry, domestic aviation, domestic shipping of goods, and the continental shelf (supply fleet) pay reduced rates. Foreign shipping, fishing in Norway, fishing in distant waters, and external aviation are all exempt from the tax. Table 3 shows Norwegian carbon tax rates by taxed sector in 2007 . The tax is estimated to cover approximately $68 \%$ of Norway's $\mathrm{CO}_{2}$ emissions, or approximately $50 \%$ of Norway's GHG emissions (UNFCCC 2006).

Table 3. Norwegian Carbon Tax Rates, 2007

\begin{tabular}{|c|c|c|}
\hline & $\begin{array}{l}\text { Tax rate - US\$ (NOK) } \\
\text { per liter oil and petrol, kg. } \\
\text { coal and coke or } \mathrm{Sm}^{3} \text { gas) }\end{array}$ & $\begin{array}{c}\text { Tax rate - NOK }(\$) \text { per } \\
\text { metric ton } \mathrm{CO}_{2}\end{array}$ \\
\hline Petrol (gasoline) & $\$ 0.14$ (0.80 NOK) & $\$ 61.76$ (345 NOK) \\
\hline \multicolumn{3}{|l|}{ Fuel oil } \\
\hline Light fuel oil, diesel & $\$ 0.10$ (0.54 NOK) & $\$ 36.34$ (203 NOK) \\
\hline Heavy fuel oils & $\$ 0.10$ (0.54 NOK) & $\$ 30.79$ (172 NOK) \\
\hline \multicolumn{3}{|l|}{ Mineral oils, lower rate } \\
\hline Light fuel oil, diesel & $\$ 0.05$ (0.28 NOK) & $\$ 18.80$ (105 NOK) \\
\hline Heavy fuel oils & $\$ 0.05$ (0.28 NOK) & $\$ 15.93$ (89 NOK) \\
\hline \multicolumn{3}{|l|}{ Use of gas in Norway } \\
\hline Natural gas & $\$ 0.08$ (0.47 NOK) & \$35.98 (201 NOK) \\
\hline LPG & $\$ 0.11$ (0.60 NOK) & $\$ 35.80$ (200 NOK) \\
\hline \multicolumn{3}{|l|}{ Continental shelf } \\
\hline Light fuel oil, diesel & $\$ 0.14$ (0.80 NOK) & $\$ 53.70$ (300 NOK) \\
\hline Heavy fuel oils & $\$ 0.14$ (0.80 NOK) & $\$ 45.65$ (255 NOK) \\
\hline Natural gas & $\$ 0.14$ (0.80 NOK) & $\$ 61.22$ (342 NOK) \\
\hline
\end{tabular}

${ }^{a} \mathrm{Sm}^{3}$ refers to a standard cubic meter.

Norway directs carbon tax revenues to general government accounts. With this revenue and revenue from offshore drilling licenses, Norway has financed a special pension fund that contained $\$ 373$ billion, or nearly $\$ 80,000$ for every Norwegian, at the end of 2007 (Turner 2008).

Norway has received negative press because its GHG emissions increased by $15 \%$ from when it implemented a carbon tax in 1991 to 2008. Others justify the increase in GHG emissions by noting that Norway also experienced an increase in gross domestic product of $70 \%$ since 1990 . (Abboud 2008)

Industrial efficiency gains in Norway may have been achieved because of the carbon tax. Emissions per unit of production were 22\% lower in 2003 than they were in 1991, but since 1996, emissions per unit of production have been steady or even rising slightly. Norwegian officials recognize that the carbon tax is not the only factor contributing to changes in industrial 
efficiency. Other factors that impact industrial efficiency include general technology improvements and the use of more mature petroleum fields, which provide increased energy per unit of production. (Ministry of the Environment, Norway 2005a)

Norway's carbon tax has promoted technology innovation in the form of carbon sequestration. In 1996, StatoilHydro, the company operating the Sleipner gas field, began developing a $\mathrm{CO}_{2-}$ sequestration project, storing $\mathrm{CO}_{2}$ under the sea floor. The project, which cost approximately $\$ 200$ million, has saved the company approximately $\$ 60$ million in carbon taxes each year and has stored approximately 1 million metric tons of $\mathrm{CO}_{2}$ annually since 1996 (UNFCCC 2006, Abboud 2008). However, even though the company has increased the efficiency of its operations, its total emissions have increased because of expansions in drilling (Abboud 2008).

\section{Sweden-1991}

In 1991, Sweden initiated a carbon tax of $\$ 44.37$ (250 SEK) per metric ton $\mathrm{CO}_{2}$. Industries, including manufacturing, agriculture, co-generation plants, forestry and aquaculture, pay a lower proportion of the general level (Ministry of Sustainable Development, Sweden 2005a). As shown in Figure 2, Sweden modified rates such that industry paid only $\$ 11.28$ (80 SEK) per metric ton while other consumers paid $\$ 45.15$ (320 SEK) per metric ton in 1993. The standard rate was $\$ 55.57$ (370 SEK) per metric ton in 1996, and between 1999 and 2003, the standard rate rose to $\$ 104.83$ (910 SEK) per metric ton while the rate for industry leveled off at approximately $\$ 23.04$ (200 SEK) per metric ton.

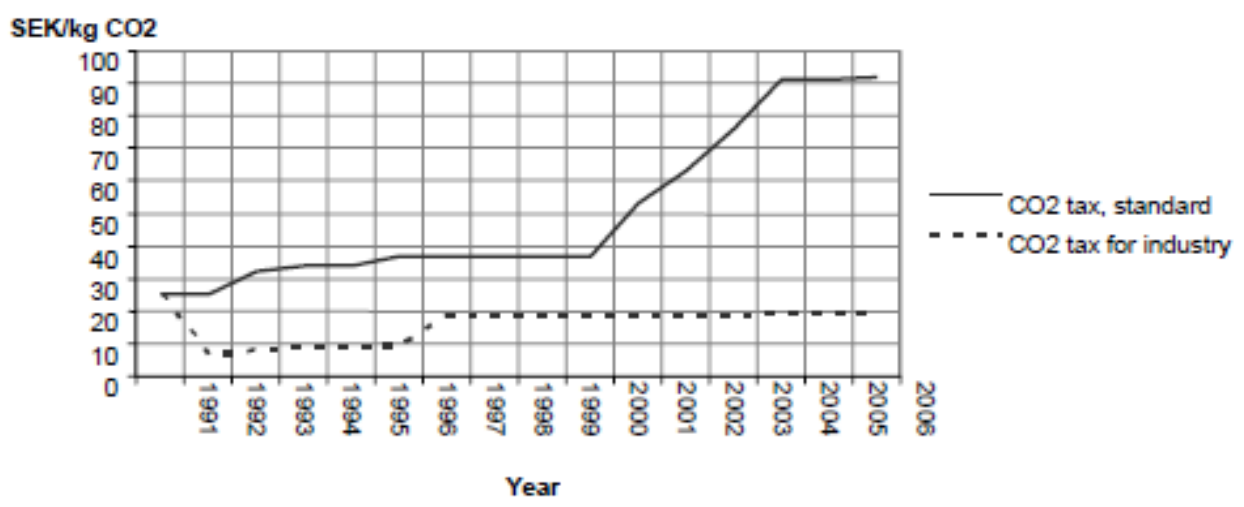

Figure 2. Swedish $\mathrm{CO}_{2}$ tax rate, SEK per kilogram $\mathrm{CO}_{2}$, nominal figures Source: Swedish Environmental Agency and Swedish Energy Agency, 2007

Revenue from Sweden's carbon tax was relatively steady from 1993 to 2000 then gradually increased from 2000 to 2004 (Figure 3). It generated approximately $\$ 3.65$ billion ( 25 billion SEK) annually in 2005, 2006, and 2007 (Swedish Tax Agency 2008a). ${ }^{4}$ Sweden directs the tax revenues to the general government budget. ${ }^{5}$

\footnotetext{
${ }^{4}$ Actual numbers: 25.810 billion SEK in 2005; 24.743 billion SEK in 2006; and 25.088 billion SEK in 2007.

${ }^{5}$ Pelle Magdalinski (Swedish Environmental Protection Agency), personal communication, December 9, 2009.
} 


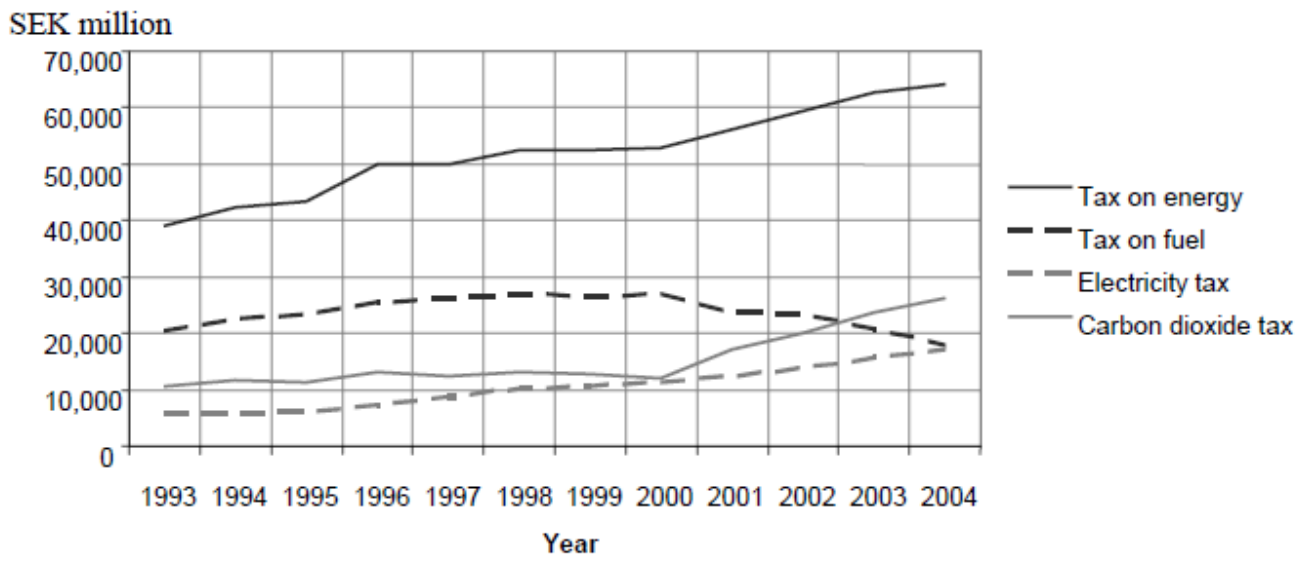

Figure 3. Swedish carbon tax revenues

Source: Swedish Environmental Agency and Swedish Energy Agency, 2007

Several studies in Sweden have attempted to assess $\mathrm{CO}_{2}$ emissions. The Swedish Ministry of the Environment estimated that $\mathrm{CO}_{2}$ emissions fell about 15\% between 1995 and 1990 because of the tax (Johansson 2000). In terms of overall emissions, Sweden saw GHG emissions fall by almost $9 \%$ between 1990 and 2006. In December 2008, Sweden reported that GHG emissions have fallen by more than $40 \%$ since the mid-1970s. (Ministry of the Environment, Sweden 2008)

Denmark-1992

Denmark's tax on $\mathrm{CO}_{2}$ passed in 1991 and took effect in May 1992. Fossil fuels are subject to both an energy tax and a $\mathrm{CO}_{2}$ tax. When the $\mathrm{CO}_{2}$ tax passed, it included a subsequent decrease in the energy tax to maintain the overall tax rate. Table 4 shows Danish energy and CO2 tax on various fuel types. The initial tax rate of $\$ 16.91$ (100 DKK) per metric ton $\mathrm{CO}_{2}$ was reduced to $\$ 16.41$ (90 DKK) per metric ton $\mathrm{CO}_{2}$ in 2005. With the decrease in the $\mathrm{CO}_{2}$ tax in 2005, the energy tax increased to maintain the overall tax rate (Speck et al. 2006). In 2008, the carbon tax rate remained at $\$ 16.41$ (90 DKK) per metric ton $\mathrm{CO}_{2}$ emissions (Ministry of Taxation, Denmark 2008). In 2008, the revenues from the $\mathrm{CO}_{2}$ tax were approximately $\$ 905$ million. 
Table 4. Danish Energy and $\mathrm{CO}_{2}$ Tax on Various Fuel Types ${ }^{\mathrm{a}}$

\begin{tabular}{|c|c|c|c|c|c|c|c|}
\hline & & 1985 & 1990 & 1996 & 2000 & 2002 & 2005 \\
\hline \multirow{3}{*}{$\begin{array}{l}\text { Light fuel oil } \\
\text { (EURcent/I) }\end{array}$} & Energy tax & 4.61 & 22.4 & 20.25 & 23.21 & 24.63 & 25 \\
\hline & $\mathrm{CO}_{2}$ tax & & & 3.67 & 3.62 & 3.63 & 3.23 \\
\hline & TOTAL TAX & 4.61 & 22.4 & 23.92 & 26.83 & 28.26 & 28.23 \\
\hline \multirow{3}{*}{$\begin{array}{l}\text { Heavy fuel oil } \\
\text { (EURcent } / \mathrm{kg} \text { ) }\end{array}$} & Energy tax & 5.11 & 25.2 & 22.56 & 26.16 & 27.72 & 28.09 \\
\hline & $\mathrm{CO}_{2} \operatorname{tax}$ & & & 4.35 & 4.29 & 4.31 & 3.9 \\
\hline & TOTAL TAX & 5.11 & 25.2 & 26.9 & 30.45 & 32.03 & 31.99 \\
\hline \multirow{3}{*}{$\begin{array}{l}\text { Natural gas } \\
\left(\text { EURcent/nm }{ }^{3}\right)^{b}\end{array}$} & Energy tax & & & 0.14 & 21.47 & 27.19 & 27.42 \\
\hline & $\mathrm{CO}_{2} \operatorname{tax}$ & & & 2.99 & 2.95 & 2.96 & 2.69 \\
\hline & TOTAL TAX & & & 3.13 & 24.42 & 30.15 & 30.11 \\
\hline \multirow{3}{*}{$\begin{array}{l}\text { Pit coal } \\
\text { (EURcent/kg) }\end{array}$} & Energy tax & 1.62 & 9.8 & 11.69 & 17.44 & 19.25 & 19.49 \\
\hline & $\mathrm{CO}_{2} \operatorname{tax}$ & & & 3.26 & 3.22 & 3.23 & 2.96 \\
\hline & TOTAL TAX & 1.62 & 9.8 & 14.95 & 20.66 & 22.47 & 22.45 \\
\hline
\end{tabular}

Source: Speck et al. 2006

${ }^{\text {a }}$ Tax rates expressed in national currencies have not been increased since 2002 with the result that current tax rates in real terms are slightly lower than they were in 2002.

${ }^{\mathrm{b}}$ The unit $\mathrm{nm}^{3}$ represents a normal cubic meter.

In Denmark, approximately $40 \%$ of tax revenue is used for environmental subsidies, while the other $60 \%$ is returned to industry. The government provides an approximately $25 \%$ reduction of the tax if a company signs an energy savings agreement with the Ministry of Transportation and Energy. Per capita emissions in Denmark were reduced by 15\% from 1990 to 2005 (Prassad 2008). Industrial emissions were also estimated to decrease by $23 \%$ during the 1990 s, after adjusting for growth and market-induced industry restructuring (Enevoldsen 2005).

\section{United Kingdom-2001}

The UK Climate Change Levy (CCL) began in 2001. It imposes a tax on electricity, natural gas supplied by a gas utility, liquefied petroleum gas or other gaseous hydrocarbons supplied in a liquid state for heating, and solid fuel (e.g., coal and coke, lignite, semi-coke of coal or lignite, and petroleum coke). CCL rates only apply to industrial and commercial energy supplies to the industrial, commercial, agricultural, public and service sectors (UK Department of Energy and Climate Change 2009). The CCL was designed to encourage businesses to become more energy efficient and reduce GHG emissions. Table 5 shows the average CCL rates as of April 1, 2009 by fuel type. 
Table 5. United Kingdom Climate Change Levy Rates as of April 1, 2009

Sector

Electricity

Natural gas as supplied by a gas utility

Liquified petroleum gas (LPG) or other gaseous hydrocarbons supplied in a liquid state, for heating

Solid fuel, e.g., coal and coke, lignite; semi-coke of coal or lignite; and petroleum coke

Source: Hatherall, 2009
Tax rate

$\$ 0.0078(£ 0.00470)$ per kWh

$\$ 0.0027$ (£0.00164) per kWh

$\$ 0.0175(£ 0.0105)$ per kg [\$0.0012 (£0.00076) per kWh]

$\$ 0.0213(£ 0.0128)$ per kg [\$0.0027 (£0.00164) per kWh]

CCL revenues in 2006-2007 were $\$ 1.191$ billion ( $£ 714$ million), far less than the approximately $\$ 2.25$ billion ( $£ 1.35$ billion) required to offset a $0.3 \%$ cut in National Insurance Contributions ${ }^{6}$ that was implemented with the CCL to make the policy revenue-neutral. ${ }^{7}$ As a result, industry as a whole has not faced higher taxes; instead, the tax burden as a whole has been reduced because the cut in National Insurance Contributions is greater than the carbon tax (UK Department of Energy and Climate Change 2009). The CCL was estimated to generate approximately $\$ 1.167$ billion (£700 million) in 2007-2008 and in 2008-2009 (Her Majesty’s Treasury 2008).

A study by Cambridge Econometrics (2005) estimated that by 2010 the CCL would reduce energy demand by approximately $15 \%$ (12.8 million metric tons) in the commercial and public sectors (Her Majesty's Treasury 2008:101).

\section{Boulder, Colorado-2007}

Boulder, Colorado, a city of approximately 100,000 people located northwest of Denver, adopted a carbon tax via a ballot initiative in 2006 . The tax, collected by the investor-owned utility, took effect in April 2007.

Rates are set based on kilowatt-hour $(\mathrm{kWh})$ use of electricity, with residents initially paying $\$ 0.0022$ per $\mathrm{kWh}$, commercial customers paying $\$ 0.0004$ per $\mathrm{kWh}$, and industrial customers paying \$0.0002 per kWh (City of Boulder 2009a). In August 2009, the tax increased to the maximum rate allowed by the tax ordinance: $\$ 0.0049$ per $\mathrm{kWh}$ for residents, $\$ 0.0009$ per $\mathrm{kWh}$ for commercial customers and $\$ 0.0003$ per $\mathrm{kWh}$ for industrial customers (City of Boulder 2009a). The rates are equivalent to approximately $\$ 12-13$ per ton of $\mathrm{CO}_{2}$. The ordinance exempts the portion of electricity that Boulder residents can voluntarily purchase as utility-provided wind power through Xcel Energy (Boulder Revised Code 3-12-2).

\footnotetext{
${ }^{6}$ National Insurance Contributions are mandatory contributions paid by employees and employers on earnings, and by employers on certain benefits-in-kind provided to employees.

${ }^{7}$ Nick Hatherall (United Kingdom Climate Change and Energy Branch), personal communication, September 18, 2009.
} 
Tax revenues were $\$ 846,885$ in 2008 and are expected to peak at $\$ 1,609,000$ in 2010 then decrease to $\$ 1,203,000$ in 2012 as fossil fuel use decreases. ${ }^{8}$ The tax is set to expire on March 31, 2013. Extension of the tax would require voter approval.

The City of Boulder uses its carbon tax revenue to fund a climate action plan that promotes energy efficiency in homes and buildings, renewable energy, and reductions in vehicle miles traveled.

Boulder developed a set of guiding principles to evaluate its carbon reduction programs. Each program must both maximize GHG reductions and be cost effective. The city measures cost effectiveness in tax dollars spent per GHG ton reduced. Programs must also include a reasonable expectation for private investment and payback time. (City of Boulder 2009a)

Boulder's goal is to reduce GHG emissions to a level that is $7 \%$ below the level of 1990 $\left(1,478,534\right.$ metric tons $\left.\mathrm{CO}_{2} \mathrm{e}^{9}\right)$ by $2012,{ }^{10}$ and it measures the success of the carbon tax in terms of meeting this goal. Boulder estimated emission reductions because of its climate action strategies as follows: (City of Boulder 2009b)

- Renewable energy activities: approximately 60,000 metric tons $\mathrm{CO}_{2} \mathrm{e}$ in 2008

- Transportation: 33,000 metric tons $\mathrm{CO}_{2} \mathrm{e}$ annually

- Energy efficiency programs: approximately 6,700 metric tons $\mathrm{CO}_{2} \mathrm{e}$ in 2008.

\section{Quebec, Canada-2007}

Quebec implemented its carbon levy in October 2007. The carbon levy is $\$ 3.20$ (C\$3.50) per metric ton of $\mathrm{CO}_{2}$. The level is readjusted every year based on the volume of sales. ${ }^{11}$ The rate varies for each fuel, with the gasoline levy at $\$ 0.0076$ ( $\mathrm{C} \$ 0.008)$ per liter, diesel fuel at $\$ 0.0086$ $(\mathrm{C} \$ 0.009)$ per liter, propane at $\$ 0.0048(\mathrm{C} \$ 0.005)$ per liter, and coal at $\$ 7.64(\mathrm{C} \$ 8.00)$ per metric ton.

According to Torys Climate Change Bulletin (2007), the carbon levy is expected to raise $\$ 191$ million (C\$200 million) annually as follows:

- $\$ 65.87$ million (C\$69 million) from gasoline producers

- $\$ 76.37$ million (C\$80 million) from diesel and heating oil producers

- $\$ 41$ million (C\$43 million) from electricity and natural gas producers

- \$6.68 million (C\$7 million) from coal and propane producers.

Quebec deposits its carbon tax revenue into a "green fund," which supports reductions in GHG emissions and improvements to public transportation. GHG-reduction measures-with the largest projected reduction in or avoidance of GHG—include (Quebec 2008):

\footnotetext{
${ }^{8}$ Sarah Van Pelt (City of Boulder), personal communication, October 9, 2009.

${ }^{9}$ Boulder performs $\mathrm{GHG}$ accounting in metric tons of carbon dioxide equivalent $\left(\mathrm{CO}_{2} \mathrm{e}\right)$

${ }^{10}$ Sarah Van Pelt (City of Boulder), personal communication, October 9, 2009.

${ }^{11}$ Robert Noel de Tilly (Senior Policy Advisor), Quebec Government, personal communication, October 8, 2009.
} 
- Requiring manufacturers of light-duty vehicles to meet a GHG-emissions standard starting in 2010

- Improving the energy efficiency in the transport of merchandise

- Financially supporting the capture and incineration or valorization of landfill gas

- Supporting manure processing and biomass

- Supporting research and innovation for carbon sequestration.

Quebec's 2006-2012 carbon mitigation action plan, Quebec and Climate Change-A Challenge for the Future (Quebec 2008), recommends 26 actions to reduce GHG emissions and adapt to climate change. The plan also is supported by $\mathrm{C} \$ 350$ million from the federal trust fund for clean air and climate change. In total, the plan is expected to reduce GHG emissions by 14.6 million metric tons by 2012 (Quebec 2008). GHG-emission reductions from programs funded by the tax are estimated at 11.2 million metric tons by $2012 .{ }^{12}$ If GHG emissions held steady at 2005 levels of 92 million metric tons, this would represent a decrease of approximately $12 \%$.

The government publishes an annual progress report, which enables it to refocus program priorities if necessary to meet its goals (Quebec 2008). It is unclear whether the government may choose to raise the carbon tax as part of this review process.

Quebec quantified GHG-reduction measures in terms of their reduction potential and total costs for the period 2006-2012. The following policies and programs are expected to be most cost effective (Quebec 2008):

- Blending a minimum of 5\% ethanol in fuel by 2012

- Reducing industrial emissions

- Financially supporting landfill gas incineration or use

- Supporting manure processing and energy use from biomass.

\section{British Columbia, Canada-2008}

British Columbia, Canada launched its carbon tax in July 2008. The tax is applied primarily to transportation fuels, natural gas, and fuels used in industrial processes. It began at a level of \$9.55 (C\$10) per metric ton $\mathrm{CO}_{2}$ and increases $\$ 4.77(\mathrm{C} \$ 5)$ per metric ton $\mathrm{CO}_{2}$ annually until reaching a level of $\$ 28.64(\mathrm{C} \$ 30)$ per metric ton of $\mathrm{CO}_{2}$ in 2012 .

In 2008, the carbon tax was estimated to be an additional $\$ 0.0223$ (C\$0.0234) per liter of gasoline. The tax will increase to approximately $\$ 0.0637$ (C\$0.0667) per liter in 2012. Natural gas is taxed at $\$ 0.47(\mathrm{C} \$ 0.50)$ per GJ, and coke is taxed at $\$ 23.74(\mathrm{C} \$ 24.87)$ per metric ton (European Environment Agency 2009). After being phased in, the government may adjust the tax rate depending on whether its GHG emissions targets are being met, the impacts other carbon policies are having, the actions other governments are taking, as well as general advice being offered by its Climate Action Team (Ministry of Finance, British Columbia 2008).

\footnotetext{
${ }^{12}$ Robert Noel de Tilly (Senior Policy Advisor), Quebec Government, personal communication, October 8, 2009.
} 
The tax base includes fuel used to generate heat for households and industrial processes such as producing cement and drying coal. In addition, the carbon tax applies to road, rail marine, and air transportation within British Columbia. Inter-jurisdictional transportation is exempt from the carbon tax.

Carbon tax revenues for the 2008-2009 fiscal year were \$292 million (C \$306 million). The tax is expected to raise $\$ 531$ million (C\$557 million) in the 2009-2010 fiscal year, \$714 million (C\$748 million) in the 2010-2011 fiscal year and \$911 million (\$955 million) in the 2011-2012 fiscal year. ${ }^{13}$

British Columbia provides a combination of tax rebates in order to make its carbon tax revenueneutral. The government provides a personal income tax rate cut, a low-income "climate action tax credit," a small business rate cut, a general corporate tax rate cut, and industrial and farm property tax cuts. In addition, British Columbia distributed a one-time check for $\mathrm{C} \$ 100$ to residents in June 2008. ${ }^{14}$

The effects of British Columbia's carbon tax are still unknown because the tax was only recently implemented. However, it was estimated that the tax would reduce emissions by 3 million metric tons annually by 2020 (Ministry of Finance, British Columbia 2008).

\section{Bay Area Air Quality Management District, California-2008}

The Bay Area Air Quality Management District (BAAQMD) incorporates nine counties of the San Francisco Bay Area. The BAAQMD established a carbon fee in July 2008, and in June 2009 , it was increased by $3 \%$ to $\$ 0.045$ per metric ton of carbon dioxide equivalent (CDE). The fee applies to GHG emissions from BAAQMD permitted facilities. The BAAQMD establishes the cost of implementing GHG reduction programs and then sets the rate by dividing the cost by the total amount of GHG emissions from BAAQMD permitted facilities (Bateman 2009). Approximately 780 facilities are subject to the fee (Bateman 2009).

The GHG fee raises revenue for BAAQMD Climate Protection Program projects related to stationary sources. Funded activities include completing and maintaining a regional GHG emissions inventory, supporting local efforts to reduce GHG emissions from stationary sources, developing regulatory measures for GHG emissions from stationary sources, reviewing GHGrelated documents, addressing climate issues in the California Environmental Quality Act, and performing administrative activities such as updating databases and invoicing (BAAQMD 2008).

The fee is expected to raise $\$ 1.1$ million for the BAAQMD (Bateman 2009). It may be raised in the future based on the funding needs of the BAAQMD Carbon Protection Program.

\section{France-Proposed}

In September 2009, French President Nicholas Sarkozy proposed a carbon tax of \$24.74 (€17) per metric ton of $\mathrm{CO}_{2}$ on fossil fuels such as gasoline, gas, and coal (Sarkozy 2009). Sarkozy proposed that the tax would not apply to electricity, saying that France's electricity is primarily carbon free (approximately $80 \%$ nuclear and approximately $10 \%$ hydroelectric). In addition, the

\footnotetext{
${ }^{13}$ Anne Foy (British Columbia Ministry of Finance), personal communication, September 17, 2009.

${ }^{14}$ Anne Foy (British Columbia Ministry of Finance), personal communication, September 17, 2009.
} 
electric sector is covered by the EU's ETS. The proposed price is based on the current market price for $\mathrm{CO}_{2}$ emissions permits through the EU (Keller 2009).

The tax would add $\$ 0.07$ ( $€ 0.045)$ for each liter of diesel, $\$ 0.06(€ 0.04)$ for each liter of gasoline, and $\$ 0.006$ (€0.004) for each kWh of natural gas consumed (Keller 2009). Sarkozy (2009) expects the tax to raise $\$ 4.499$ billion ( $€ 3$ billion). Tax rates are expected to increase over time; however, the level of increase has not been presented.

The proposal indicated that the tax would be accompanied by a reduction in taxes for households and businesses or repaid through a "green check" (Keller 2009).

\section{California Air Resource Board-Proposed}

The California Air Resources Board (CARB), under the authority of California's Assembly Bill 32 (AB 32), the Global Warming Solutions Act of 2006, adopted a carbon fee in September 2009 and is in the rulemaking process to institute the fee (CARB 2009a).

The CARB staff proposal for the fee would cover $85 \%$ of California's GHG emissions through regulation of approximately 350 sources, including large natural gas distributers and large users of natural gas, producers or importers of gasoline or diesel fuel, facilities that combust coal and petroleum coke, refineries, cement manufacturers, and electricity importers and in-state generating facilities (CARB 2009b).

The preliminary proposed costs for the fee in fiscal year $2010-2011$ are $\$ 0.155$ per metric ton $\mathrm{CO}_{2}$ equivalent. CARB established the fee by calculating the revenue requirement to implement GHG reduction programs, and then dividing by the estimated GHG emissions by covered sectors. The fee was not designed to place a value on carbon high enough to change behavior but rather to provide a continuous funding source to implement AB 32.

The fee is expected to raise $\$ 63.1$ million during the first three years of implementation, in part to cover loans the programs have received in fiscal years 2007-2008, 2008-2009, and 2009-2010. The fee is proposed to be reduced to $\$ 0.09$ per metric ton of $\mathrm{CO}_{2}$ in 2014 -after loans are paid off — and generate an estimated $\$ 36.2$ million per year thereafter.

The fee is not designed to change purchase behavior but would fund the administration, implementation, and enforcement of GHG emission reduction measures in the AB 32 scoping plan, which was designed to help California meet its GHG reduction goals (CARB 2008). In this way, the CARB fee more closely represents an administrative cost-covering fee than a traditional carbon tax. The polluting entity in this system is paying to cover the costs to administer a program to regulate emission. (See Ekins 1999) 


\section{Effectiveness of Carbon Taxes}

While the primary purpose of carbon taxes is to reduce GHG emissions, most existing carbon policies introduce no processes or specific requirements to evaluate policy effectiveness in reducing emissions, although some attempted to assess their effects. Determining the overall impacts of a carbon tax can be challenging because many factors can affect overall carbon dioxide emissions, including economic growth levels and other programs designed to address environmental impacts. ${ }^{15}$ Even so, measurement, tracking, and program evaluation are important to determine the impact of the policy, especially if emissions reductions are the ultimate goal.

\section{Evaluation of Emissions Benefits of Carbon Taxes}

Jurisdictions have used a variety of metrics to determine the emission benefits of carbon taxes. One of the most rudimentary metrics for measuring carbon tax effectiveness is overall reductions in GHG emissions that can be tracked using GHG emissions inventories at the national or local level. This metric is flawed in that it captures not only the carbon tax effects but also the effects of other carbon mitigation polices and exogenous variables such as the level of economic growth. While this metric lacks precision, jurisdictions can use it to evaluate whether they are meeting overall GHG reduction goals and to determine whether policies, including carbon taxes, should be modified accordingly.

Examining the effects of a carbon tax alone on GHG emissions would provide a more precise estimation of policy effectiveness. Many governments model the effects of a carbon tax acting alone during the implementation phase of the tax. For example, in the United Kingdom, according to a modeling study by Cambridge Econometrics (2005), the Climate Change Levy would reduce energy demand by approximately $15 \%$ (12.8 million metric tons) in the commercial and public sectors by 2010 (Her Majesty's Treasury 2008:101). However, determining the actual impact of a tax in isolation of other factors is often difficult, and most evaluations have not attempted to do so. Because of the lack of common evaluation practices, it is difficult to compare the effects of policies across jurisdictions. Table 6 summarizes evaluations of either carbon emissions levels or program effectiveness that jurisdictions have conducted to gauge the impact of carbon taxes. For example, Sweden's emissions were reduced by almost $9 \%$ between 1990 and 2006, while in Denmark, per capita emissions were reduced by 15\% between 1990 and 2005.

\footnotetext{
${ }^{15}$ Evaluation may be easier to implement for taxes designed to raise revenues to implement specific carbon reduction programs.
} 
Table 6. Estimated Emissions Reductions in Jurisdictions with Carbon Taxes ${ }^{\text {a }}$

Unless otherwise noted, decreases in emissions represent total emission reductions, not emission reductions that are due to a carbon tax.

\begin{tabular}{|c|c|c|c|}
\hline Jurisdiction & $\begin{array}{l}\text { Start } \\
\text { Date }\end{array}$ & Change in $\mathrm{CO}_{2}$ Emissions & Source \\
\hline Finland & 1990 & $\begin{array}{l}\text { Emissions were } 7 \% \text { lower in } 1998 \text { than they would have } \\
\text { been without a tax. }\end{array}$ & $\begin{array}{l}\text { Prime Minister's Office, } \\
\text { Finland (2000) }\end{array}$ \\
\hline Netherlands & 1990 & $\begin{array}{l}\text { Emissions were expected to be reduced by } 1.7 \text { to } 2.7 \\
\text { million metric tons } \mathrm{CO}_{2} \text { annually in } 2000 \text {. In covered } \\
\text { sectors, emissions were expected to be reduced by } \\
\text { approximately } 5 \% \text {. }\end{array}$ & $\begin{array}{l}\text { Netherlands Ministry of } \\
\text { Housing, Spatial } \\
\text { Planning and the } \\
\text { Environment (n.d.) }\end{array}$ \\
\hline Norway & 1991 & $\begin{array}{l}\text { Emissions increased by } 15 \% \text {-and GDP increased } 70 \% \text { - } \\
\text { from } 1991 \text { to } 2008 \text {. }\end{array}$ & Abboud (2008) \\
\hline \multirow[t]{3}{*}{ Sweden } & \multirow[t]{3}{*}{1991} & $\begin{array}{l}\text { Emissions were reduced by about 15\% from } 1990 \text { to } 1996 \\
\text { because of the carbon tax. }\end{array}$ & Johansson (2000) \\
\hline & & Emissions decreased by $9 \%$ from 1990 to 2006. & \multirow{2}{*}{$\begin{array}{l}\text { Ministry of the } \\
\text { Environment, Sweden } \\
\text { (2008) }\end{array}$} \\
\hline & & $\begin{array}{l}\text { Emissions decreased by more than } 40 \% \text { from the mid- } \\
1970 \text { s to } 2008 \text {. }\end{array}$ & \\
\hline Denmark & 1992 & $\begin{array}{l}\text { Emissions decreased by } 15 \% \text { per capita from } 1990 \text { to } \\
2005 \text {. }\end{array}$ & Prassad (2008) \\
\hline \multirow[t]{2}{*}{$\begin{array}{l}\text { United } \\
\text { Kingdom }\end{array}$} & \multirow[t]{2}{*}{2001} & $\begin{array}{l}\text { Emissions decreased by more than } 58 \text { million metric tons } \\
\mathrm{CO}_{2} \text { from } 2001 \text { to } 2005 \text {. }\end{array}$ & \multirow{2}{*}{$\begin{array}{l}\text { Cambridge } \\
\text { Econometrics (2005) } \\
\text { cited in Her Majesty's } \\
\text { Treasury (2008:101) }\end{array}$} \\
\hline & & $\begin{array}{l}\text { Emissions are expected to be reduced by } 12.8 \text { million } \\
\text { metric tons } \mathrm{CO}_{2} \text { per year ( } 15 \% \text { of commercial and public } \\
\text { sector energy demand) in } 2010 \text { because of the Climate } \\
\text { Change Levy. }\end{array}$ & \\
\hline Boulder, CO & 2007 & $\begin{array}{l}\text { Emissions in } 2007 \text { and } 2008 \text { decreased from } 2006 \text { levels. } \\
\text { Greatest reductions due to programs funded by the carbon } \\
\text { tax: } \\
\text { - Renewable energy activities }\left(60,000 \text { metric tons } \mathrm{CO}_{2} \mathrm{e}\right) \\
\text { - Transportation }\left(33,000 \text { metric tons } \mathrm{CO}_{2} \mathrm{e}\right) \\
\text { - Energy efficiency }\left(6,700 \text { metric tons } \mathrm{CO}_{2} \mathrm{e}\right)\end{array}$ & City of Boulder (2009b \\
\hline Quebec & 2007 & $\begin{array}{l}\text { Emissions were expected to be reduced by } 11.2 \text { million } \\
\text { metric tons } \mathrm{CO}_{2} \text { by } 2012 \text { due to the carbon tax. }\end{array}$ & Quebec (2008) \\
\hline $\begin{array}{l}\text { British } \\
\text { Columbia }\end{array}$ & 2008 & $\begin{array}{l}\text { GHG emissions were expected to be reduced emissions by } \\
\text { up to } 3 \text { million metric tons } \mathrm{CO}_{2} \text { annually in } 2020 \text { due to the } \\
\text { tax. }\end{array}$ & $\begin{array}{l}\text { Ministry of Finance, } \\
\text { British Columbia (2008) }\end{array}$ \\
\hline
\end{tabular}

${ }^{a}$ BAAQMD implemented a carbon tax in 2008 and is tracking data but has not issued a report.

France and CARB each proposed but have not implemented a program. 


\section{Benefits of Programs Funded by Carbon Tax Revenues}

The impacts of programs funded by specific carbon mitigation measures can be quantified to determine program effectiveness. With such program evaluations, governments administering carbon taxes can change the rate or shift funds to programs that are more effective at reducing emissions. For example, each year the City of Boulder evaluates programs funded through its carbon tax. In July 2009, the Boulder City Council approved an increase in the carbon tax level and targeted the additional revenue at expanding program offerings, including energy efficiency improvements and mass transit programs. (City of Boulder 2009a).

Estimating the impacts of individual programs funded through a tax may be easier than estimating the impacts of the tax itself, as most programs are targeted toward specific reductions that typically can be measured. For example, it is possible to calculate the cost per metric ton of $\mathrm{CO}_{2} \mathrm{e}$ emissions over the lifetime of the project. Boulder used such a metric and found that energy efficiency programs provided the most cost effective programs. However, reductions from some programs, such as education and outreach, may be difficult to quantify.

\section{Program Evaluation and Adjustments to Carbon Tax Levels}

Linking a carbon tax level to the achievement of emissions goals emphasizes the need for accurate emissions tracking and evaluation. Ideally, the methodology for measuring emissions would be clearly articulated before the tax is implemented. Some jurisdictions, such as countries that are signatories to the United Nations Framework Convention on Climate Change, may already be completing greenhouse gas inventories.

Most carbon taxes were not designed to adjust depending on emissions levels. In British Columbia, however, the government specified that future changes in the tax rate will depend on whether GHG emissions targets are being met, the impacts other carbon policies are having, the actions other governments are taking, as well as general advice being offered by its Climate Action Team (Ministry of Finance, British Columbia 2008). Because the tax is new, this evaluation and adjustment have not yet been implemented. 


\section{Integration of Taxes and Other Carbon Policies}

A government trying to achieve GHG reductions in its entire economy may implement a carbon tax in conjunction with complementary policies. Taxes can be an attractive option for addressing emissions that might be difficult to regulate through other mechanisms such as cap and trade or command and control regulation. For example, Norway's carbon tax covers about $68 \%$ of $\mathrm{CO}_{2}$ emissions, which represents more than half of its total GHG emissions. By comparison, Norway's participation in the EU's Emission Trading Scheme (ETS) covers 35\%-40\% of its GHG emissions (Ministry of the Environment, Norway 2008). In addition to its carbon tax, Norway implemented a tax on the import and production of other GHGs including HFCs and PFCs, which have high global warming rate potentials. Emissions from these sources are expected to be cut in half because of this tax (Ministry of the Environment, Norway 2005b).

Carbon taxes have generally been limited to certain sectors of the economy. For example, carbon taxes in Sweden address the energy and transport sectors but rely on other GHG-reduction strategies to reduce overall GHG emissions. Sweden has added cross-sectoral instruments such as participating in the EU's ETS, investing in research and development and local programs, and developing policies to addresses the waste sector (Ministry of Sustainable Development, Sweden 2005b).

Like Sweden, Finland participates in the EU's ETS. Businesses are subject to both the ETS and the carbon tax, but to date Finland has allocated emissions allowances under the ETS free of charge (Parkkinen 2009). Finland has also developed building code regulations, waste management policies, and $\mathrm{CO}_{2}$-based rates for vehicle registration taxes and annual vehicle taxes (Parkkinen 2009).

In the United Kingdom, businesses subject to the Climate Change Levy (CCL) can sign climate change agreements with the government to reduce emissions, and after achieving targets, can receive an $80 \%$ reduction in the CCL. One way businesses can meet their targets is through purchasing allowances through the EU's ETS (UK Department for Environment, Food and Rural Affairs 2005).

France has also looked to the EU's ETS to set its tax rate. President Sarkozy's proposed carbon tax would initially be set at the same level as the current market price for carbon in the ETS. The proposed tax would apply to oil, gas, and coal but not industries already participating in the ETS (BBC News 2009). 


\section{Conclusions and Observations}

Federal, state, and local governments are increasingly interested in instituting carbon taxes as a mechanism for addressing GHG emissions. While a handful of taxes were implemented in Europe in the early 1990s, few were adopted in the interim until a resurgence of interest on the part of local and state governments in recent years. Since 2007, new carbon taxes have been implemented in parts of Canada and the United States, while a number of others have been proposed.

Policy designs for carbon taxes vary according to the jurisdiction's policy goals. Some carbon taxes have been designed to encourage behavior changes and represent cost increases to fuel use as much as $\$ 30$ per metric ton $\mathrm{CO}_{2}$ or more. Other carbon taxes have been designed to raise revenues for specific carbon mitigation programs and, in some cases, are implemented at levels that are not likely to drive behavioral changes.

The use of revenues derived from carbon taxes varies considerably. Half of the taxes implemented to date return revenues to the government or entities subject to the tax to offset the burden, while the rest use revenues to fund either specific carbon mitigation programs or government budgets. Some policies apply a portion of revenues for each purpose.

Carbon taxes have been - and can be - used to address emissions from sectors that may not be easily addressed through cap and trade policies because of concerns about the point of regulation or emissions tracking. For example, non-stationary sources such as vehicle emissions can be difficult to address through a cap and trade system. Taxes have been most commonly applied to natural gas, gasoline, coal, electricity, and fuel oils.

Some carbon taxes target specific gaps and address areas not supported through other activities. As a result, carbon taxes can be integrated with other carbon policies in complementary ways.

Efforts to evaluate the effectiveness of existing carbon taxes have been limited. Some studies assessing carbon emissions levels in countries that instituted taxes in the early 1990s show overall GHG emissions reductions, with some as high as $15 \%$. However, these studies have generally not attempted to account for the impact of other carbon mitigation policies. Most recently implemented carbon taxes emphasize evaluation and estimating impacts, but their effectiveness remains to be seen.

While it is possible to track and adjust tax levels over time to meet emissions goals, few jurisdictions have implemented such practices. British Columbia designed its new carbon tax with tracking and adjustments in mind, but the tax is so new, there has been no practical experience adjusting the tax level to meet emissions goals. Remaining to be seen are whether raising carbon tax levels entails political difficulties and how progress toward emissions goals will be evaluated; however, taxes designed with tracking and adjustments in mind hold promise as another means of achieving GHG emissions reduction goals. 
Many questions still exist for future consideration.

- While carbon policy has seen greater interest at the federal level in the United States, to what degree will state and local governments pursue carbon taxes as a means for mitigating climate change?

- How would current and proposed carbon taxes in the United States interact with regional or federal cap and trade policies?

- When a carbon tax is set at a rate high enough to impact consumer behavior, how does the point of regulation affect consumer awareness? If the tax is imposed on upstream sources and consumers do not see a direct correlation between their consumption and the level of the tax they pay, they may be less likely to change consumption behavior. Boulder's tax appears on consumers' utility bills, but carbon taxes in other jurisdictions may not be directly visible to the consumer.

- As carbon accounting and carbon registries become more advanced, will carbon taxes include life-cycle emissions of sources? 


\section{References}

Abboud, L. (2008). An exhausting war on emissions: Norway's efforts to contain greenhouse gases move forward-and backfire. Wall Street Journal, September 30, 2008. http://online.wsj. com/article/SB122272533893187737.html Accessed December 28, 2009.

Bateman, B. (2009). "Bay Area Air Quality Management District greenhouse gas fee schedule." Presented at the Center for Climate Change webinar. August 25, 2009.

Bay Area Air Quality Management District (BAAQMD). (2008). "Fact sheet: Proposed Bay Area Air Quality Management District greenhouse gas fee schedule." February 5, 2009. http://www.baaqmd.gov/Divisions/Planning-and-Research/Planning-Programs-and-Initiatives/ Climate-Protection-Program/ /media/6D9F5ACC2B674F698BFD77D339C3D535.ashx Accessed December 28, 2009.

BBC News. (2009). "France set to impose carbon tax." Sept. 10, 2009. http://news.bbc.co.uk/2/hi/8248392.stm Accessed December 28, 2009.

Boulder Revised Code. 3-12-2. "Imposition of climate action plan excise tax." http://www .colocode.com/boulder2/chapter3-12.htm Accessed December 28, 2009.

California Air Resources Board (CARB). (2008). "Climate change scoping plan: A framework for change." http://www.arb.ca.gov/cc/scopingplan/document/adopted scoping plan.pdf Accessed December 28, 2009.

CARB. (2009a). "AB 32 cost of implementation fee regulation (HSC 38597)." http://www.arb.ca.gov/cc/adminfee/adminfee.htm Accessed November 4, 2009.

CARB. (2009b). "Proposed AB 32 cost of implementation fee regulation and proposed amendment to the mandatory reporting of greenhouse gas emissions regulation." September 25, 2009. http://www.arb.ca.gov/cc/adminfee/meetings/sept 25 board presentation.pdf Accessed October 8, 2009.

City of Boulder. (2009a). "An ordinance amending the climate action plan excise taxes to the maximum rates set forth in section 3-12-2, B.R.C. 1981, and setting forth details in relation thereto." Ordinance No. 7657. http://www.colocode.com/boulder2/chapter3-12.htm Accessed December 28, 2009.

City of Boulder. (2009b). "Community guide to Boulder's climate action plan." October 2009. http://www.bouldercolorado.gov/files/CAP_Guide.pdf Accessed December 28, 2009.

Congressional Budget Office. (2008). Policy options for reducing $\mathrm{CO}_{2}$ emissions. February 2008. No. 2930. Washington, DC: Congressional Budget Office. http://www.cbo.gov/doc.cfm ?index=8934 Accessed December 28, 2009.

Ekins, P. (1999). "European environmental taxes and charges: Recent experience, issues and trends." Ecological Economics (31): pp. 39-62. 
Ellerman, A. D.; Joskow, P. L. (2008). The European Union's emissions trading system in perspective. May 2008. Arlington, VA: Pew Center on Global Climate Change. http://www. pewclimate.org/docUploads/EU-ETS-In-Perspective-Report.pdf Accessed December 28, 2009.

Enevoldsen, M. (2005). The theory of environmental agreements and taxes: $\mathrm{CO}_{2}$ Policy performance in comparative perspective. London: Edward Elgar.

European Environment Agency. (2009). OECD/EEA database on instruments used for environmental policy and natural resources management. http://www2.oecd.org/ecoinst/queries/ Accessed November 3, 2009.

Goulder, L. H. (1995). "Environmental taxation and the double dividend: A reader's guide." International Tax and Public Finance (2): pp. 157-183.

Johansson, B. (2000). "The carbon tax in Sweden," Chapter 5. Innovation and the environment: OECD proceedings. http://books.google.com/books?id=Y1PBGIQQ6vAC\&dq=Innovation+ and + the + Environment: + OECD + Proceeding\&printsec $=$ frontcover\&source $=$ bn\&hl $=$ en\&ei $=$ aWsyS7GbOoWLnQfMh4n2CA\&sa=X\&oi=book result\&ct=result\&resnum=4\&ved= 0CBIQ6AEwAw\# $\mathrm{v}=$ onepage $\& \mathrm{q}=\& \mathrm{f}=$ false Accessed December 28, 2009.

Keller, G. (2009). France's Sarkozy urges carbon tax. Breitbart, September 10, 2009. http://www.breitbart.com/article.php?id=D9AKFI3G2 Accessed December 28, 2009.

Her Majesty's Treasury. (2008). Budget 2008: Stability and opportunity: Building a strong, sustainable future. HC 388. London: The Stationery Office. http://www.hm-treasury.gov.uk/d/ bud08_completereport.pdf Accessed December 28, 2009.

Ministry of Finance, British Columbia. (2008). "Budget and Fiscal Plan 2008/09-2010/11.” February 19, 2008. http://www.bcbudget.gov.bc.ca/2008/bfp/2008_Budget_Fiscal_Plan.pdf Accessed December 28, 2009.

Ministry of Sustainable Development, Sweden. (2005a). The Swedish report on demonstrable progress under the Kyoto Protocol. Ds 2005:57. http://unfccc.int/resource/docs/dpr/swe1.pdf Accessed November 4, 2009.

Ministry of Sustainable Development, Sweden. (2005b). Sweden's fourth national communication on climate change under the United Nations Framework Convention on Climate Change. Ds 2005:55. http://unfccc.int/resource/docs/natc/swenc4.pdf Accessed November 3, 2009.

Ministry of Taxation, Denmark. (2008). "VAT, payroll tax and environmental taxes." June 23, 2008. http://www.skm.dk/foreign/english/taxindenmark2008/6649/ Accessed December 28, 2009 .

Ministry of the Environment, Finland. (2008a). "Detailed information on environment-related taxes and charges in Finland." http://www.environment.fi/download.asp? contentid=85625 Accessed Oct. 7, 2009. 
Ministry of the Environment, Finland. (2008b). "Environmentally related energy taxation in Finland.” http://www.environment.fi/default.asp?contentid=147208 Accessed Oct. 7, 2009.

Ministry of the Environment, Norway. (2005a). Norway's fourth national communication under the Framework Convention on Climate Change: Status report as of December 2005.

T-1452 E. http://unfccc.int/resource/docs/natc/nornc4.pdf Accessed December 14, 2009.

Ministry of the Environment, Norway. (2005b). Norway's report on demonstrable progress under the Kyoto Protocol: Status report as of December 2005. T-1453 E. http://unfccc.int/ resource/docs/dpr/nor1.pdf Accessed November 4, 2009.

Ministry of the Environment, Norway. (2007). Norwegian climate policy: Summary in English: Report No. 34 (2006-2007) to the Storting. http://www.regjeringen.no/pages/2065909/PDFS/ STM200620070034000EN PDFS.pdf Accessed November 3, 2009.

Ministry of the Environment, Norway. (2008). "Norwegian national allocation plan for the emissions trading system in 2008-2012." March 2008. http://www.regjeringen.no/upload/MD/ Vedlegg/Planer/NAP FINAL ESA 260308.pdf Accessed December 11, 2009.

Ministry of the Environment, Sweden, (2008). "Towards a low carbon society." M2008.30. http://www.sweden.gov.se/content/1/c6/11/66/69/f7b9ac55.pdf Accessed Nov. 4, 2009.

Netherlands Ministry of Housing, Spatial Planning and the Environment, Directorate-General for Environmental Protection. (n.d.). "The Netherlands' tax on energy: Questions and answers." http://www.wind-works.org/FeedLaws/Netherlands/NLEnergytax2004.pdf Accessed October 7, 2009.

Nordhaus, W. (2008). A question of balance: Weighing the options on global warming policies. New Haven, CT: Yale University Press.

Organisation for Economic Co-operation and Development (OECD). (2001). Environmentally related taxes in OECD countries - Issues and strategies. Cited in EUROSTAT (2003) Energy taxes in the Nordic countries - does the polluter pay? Final report. March. http://www.scb.se/statistik/MI/MI1202/2004A01/MI1202_2004A01_BR_MIFT0404.pdf Accessed December 28, 2009.

Parkkinen, Timo (Ministry of the Environment, Finland). (2009). Personal communication, October 8, 2009.

Prasad, M. (2008). "Taxation as a regulatory tool: Lessons from environmental taxes in Europe." Tobin Project Conference "Toward a New Theory of Regulation.” February 1-3, 2008. http://www.sociology.northwestern.edu/faculty/prasad/Taxation_3_25 08 Accessed December 28, 2009.

Prime Minister's Office, Finland. (2000). Environmental and energy taxation in Finland Preparing for the Kyoto Challenge: Summary of the working group report. http://www.vnk.fi/ julkaisut/julkaisusarja/julkaisu/fi.jsp?oid=130600 Accessed December 28, 2009. 
Quebec. (2008). “Quebec and climate change: A challenge for the future. 2006-2012 Action plan.” June 2008. http://www.mddep.gouv.qc.ca/changements/plan_action/2006-2012_en.pdf Accessed October 8, 2009.

Repetto, R. (2001). "Yes, Virginia, there is a double dividend." University of Colorado at Denver. http://www.cudenver.edu/Academics/Colleges/SPA/CommunityOutreach/Centers/ WirthChair/publications/Documents/1996-2001/Yes,\%20Virginia.pdf Accessed December 10, 2009.

Sarkozy, N. (2009). "France's strategy in the fight against climate change: Speech by Nicolas Sarkozy, President of the Republic - Excerpts." September 10, 2009. https://pastel.diplomatie .gouv.fr/editorial/actual/ael2/bulletin.gb.asp?liste=20090914.gb.html Accessed November 4, 2009.

Speck, S.; Andersen, M. K.; Nielsen, H. Ø.; Ryelund, A.; Smith, C. (2006). The use of economic instruments in Nordic and Baltic environmental policy 2001-2005. 2006:525. Copenhagen:

Nordic Council of Ministers. http://www.norden.org/da/publikationer/publikationer/2006-525/ Accessed November 3, 2009.

Swedish Tax Agency (2008a). Taxes in Sweden: An English summary of tax statistical yearbook of Sweden. http://www.skatteverket.se/download/

18.69ef368911e1304a625800017687/10409.pdf Accessed November 3, 2009.

Torys LLP. (2007). "Quebec government to implement carbon tax.” Torys Climate Change Bulletin. June 12, 2007. http://www.torys.com/Publications/Documents/Publication PDFs/ CCB2007-6.pdf Accessed October 8, 2009.

Turner, C. (2008). “The carbon cleansers.” Canadian Geographic. October 2008. http://www.canadiangeographic.ca/magazine/oct08/feature_norway_carbon_tax.asp

UK Department for Environment, Food and Rural Affairs. (2005). “The United Kingdom's report on demonstrable progress under the Kyoto Protocol.” http://unfccc.int/resource/docs/dpr/ uk1.pdf Accessed Nov. 4, 2009.

UK Department of Energy and Climate Change. (2009). "Climate change agreements: The Climate Change Levy." http://www.decc.gov.uk/en/content/cms/what_we_do/change_energy/ tackling_clima/ccas/cc levy/cc levy.aspx Accessed November 3, 2009.

United Nations Framework Convention on Climate Change (UNFCCC) Compliance Committee. (2006). Report of the centralized in-depth review of the fourth national communication of Norway. CC/ERT/2006/8. http://unfccc.int/files/kyoto protocol/compliance/plenary/application/ pdf/cc-ert-2006-8_report of centralized_idr_of nc4 of norway.pdf Accessed November 3, 2009. 


\section{Bibiliography}

Swedish Environmental Agency and Swedish Energy Agency (2007). "Economic instruments in environmental policy." February 2007. Report 5678. Stockholm: Swedish Environmental Agency. http://www.energimyndigheten.se/Global/Engelska/News/620-5678-6_webb.pdf Accessed November 3, 2009.

Swedish Tax Agency (2008b). Facts about Swedish excise duties 2008. http://www.skatteverket .se/download/18.225c96e811ae46c823f80007801/493b14.pdf Accessed November 3, 2009. 


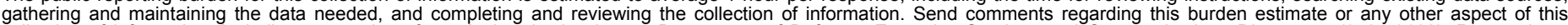

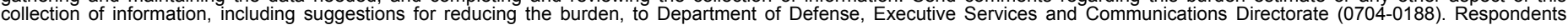

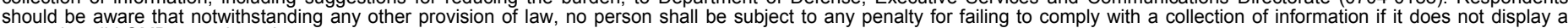

should be aware that notwithstanding

PLEASE DO NOT RETURN YOUR FORM TO THE ABOVE ORGANIZATION.

\begin{tabular}{l|l|l|l} 
1. REPORT DATE $(D D-M M-Y Y Y Y)$ & 2. REPORT TYPE & 3. DATES COVERED (FrOm - TO)
\end{tabular}

December 2009

Technical Report

4. TITLE AND SUBTITLE
Carbon Taxes: A Review of Experience and Policy Design

Considerations

5a. CONTRACT NUMBER

DE-AC36-08-GO28308

5b. GRANT NUMBER

5c. PROGRAM ELEMENT NUMBER

6. AUTHOR(S)

J. Sumner, L. Bird, and H. Smith

5d. PROJECT NUMBER

NREL/TP-6A2-47312

5e. TASK NUMBER

SAO9.2034

5f. WORK UNIT NUMBER

7. PERFORMING ORGANIZATION NAME(S) AND ADDRESS(ES)

National Renewable Energy Laboratory

1617 Cole Blvd.

Golden, CO 80401-3393

9. SPONSORING/MONITORING AGENCY NAME(S) AND ADDRESS(ES)

10. SPONSOR/MONITOR'S ACRONYM(S) NREL

11. SPONSORING/MONITORING AGENCY REPORT NUMBER

12. DISTRIBUTION AVAILABILITY STATEMENT

National Technical Information Service

U.S. Department of Commerce

5285 Port Royal Road

Springfield, VA 22161

13. SUPPLEMENTARY NOTES

14. ABSTRACT (Maximum 200 Words)

State and local governments in the United States are evaluating a wide range of policies to reduce carbon emissions, including, in some instances, carbon taxes, which have existed internationally for nearly 20 years. This report reviews existing carbon tax policies both internationally and in the United States. It also analyzes carbon policy design and effectiveness. Design considerations include which sectors to tax, where to set the tax rate, how to use tax revenues, what the impact will be on consumers, and how to ensure emissions reduction goals are achieved. Emission reductions that are due to carbon taxes can be difficult to measure, though some jurisdictions have quantified reductions in overall emissions and other jurisdictions have examined impacts that are due to programs funded by carbon tax revenues.

15. SUBJECT TERMS

United States; carbon taxes; carbon tax; carbon policies; carbon policy; states; state government; local governments; carbon emissions; emission reductions; carbon policy design; tax sectors; tax rates; tax revenues; carbon tax rates; effectiveness; gasoline; coal; natural gas; Boulder, Colorado; California; Denmark; Finland; France; Netherlands; Norway; Quebec, Canada; Sweden; United Kingdom

\begin{tabular}{|c|c|c|c|c|}
\hline \multicolumn{3}{|c|}{ 16. SECURITY CLASSIFICATION OF: } & \multirow{2}{*}{$\begin{array}{l}\text { 17. LIMITATION } \\
\text { OF ABSTRACT } \\
\text { UL }\end{array}$} & \multirow{2}{*}{$\begin{array}{ll}\text { 18. } & \text { NUMBER } \\
& \text { OF PAGES }\end{array}$} \\
\hline $\begin{array}{l}\text { a. REPORT } \\
\text { Unclassified }\end{array}$ & $\begin{array}{l}\text { b. ABSTRACT } \\
\text { Unclassified }\end{array}$ & $\begin{array}{l}\text { c. THIS PAGE } \\
\text { Unclassified }\end{array}$ & & \\
\hline
\end{tabular}

19a. NAME OF RESPONSIBLE PERSON

19b. TELEPHONE NUMBER (Include area code) 